Article

\title{
Sustainability and Effectiveness of Chinese Outline for National Tourism and Leisure
}

\author{
Emanuele Giorgi $1,2, * \mathbb{C}$, Tiziano Cattaneo ${ }^{2,3}$, Minqing $\mathrm{Ni}^{3}$ and Renata Enríquez Alatriste 4 \\ 1 Tecnologico de Monterrey, Escuela de Arquitectura, Arte y Diseño, Campus Chihuahua, Av. H. Colegio \\ Militar 4700, Nombre de Dios, Chihuahua 31300, Mexico \\ 2 China Lab. for Architecture and Urban Studies, Department of Civil Engineering and Architecture, \\ University of Pavia, Via Ferrata 1, 27100 Pavia, Italy; tiziano.cattaneo@tongji.edu.cn or \\ tiziano.cattaneo@unipv.it \\ 3 Environmental Futures Lab., College of Design and Innovation, Tongji University, n. 281 Fuxin Road, \\ Yangpu District, Shanghai 200092, China; niminqing@tongji.edu.cn \\ 4 Tecnologico de Monterrey, Escuela de Arquitectura, Arte y Diseño, Eugenio Garza Sada S/N, Predio Cerro \\ Gordo, León 37190, Mexico; renatanrqz@gmail.com \\ * Correspondence: egiorgi@tec.mx
}

Received: 8 November 2019; Accepted: 17 January 2020; Published: 6 February 2020

check for updates

\begin{abstract}
This study is addressed to understand: (1) how the Chinese policies for tourism meet the international guidelines for sustainable development promoted by the United Nations, through the 17 Sustainable Development Goals (SDGs) and (2) how the Chinese policies for tourism are applied in reality by design practice. To answer these two research questions, the research considers mainly three groups of reference sources: the 2030 Agenda for Sustainable Development; the Outline for National Tourism and Leisure 2013-2020 (ONTL) of the Chinese Government and their analyses from independent sources; the descriptions of architectural interventions for hospitality. According with the two research questions, the research is based on two phases: (1) a comparison between the Chinese policies for tourism development and the international policies for sustainable development; (2) a search of sustainable policies in the design practice, through the analysis of 30 projects for hospitality, realized in China after 2013. The results of both the phases propose a new paradigm in understanding China's role as a country leading sustainable tourism for development.
\end{abstract}

Keywords: sustainable tourism; Chinese tourism; design and policies

\section{Theoretical Framework and Review of the Art for Chinese Tourism and Public Policies}

In recent decades, Travel and Tourism have become a force with strong impacts on the economy, social phenomena, consumption of resources and territory. While the countries, aware of tourism's potentialities, compete to lead this sector, governments and communities are more and more conscious about the dangers that tourism's development can bring [1]. If we have a look at the dimension of the phenomenon in 2016, we can understand, thanks to the report of World Travel and Tourism Council, [2] the global importance of tourism, which, in this year contributed directly to US\$2.3 trillion and 109 million jobs worldwide. Moreover, if we also consider the indirect and induced impact, this sector contributed to US $\$ 7.6$ trillion to the global economy and 292 million jobs, which is equal to $10.2 \%$ of the world's GDP and approximately 1 in 10 of all jobs. Still according to this report, Travel \& Tourism, which is composed by $76.8 \%$ of leisure travels and by $23.2 \%$ of business travels, has the larger contribution in the generation of GDP by domestic travel generated $(72 \%)$ and a minority of foreign visitors $(28 \%)$. If the magnitude of this phenomenon is incredibly relevant globally, this is even truer for the Chinese reality, where (1) economic, cultural and social changes are happening with incredible strength and rapidity and (2) the dimension of the country and the complexity of the local 
realities contribute in creating innumerable factors, influencing Chinese market and entrepreneurial opportunities [3,4]. In particular, one of the biggest phenomena, still ongoing, is the rural-urban migration with all the well known consequences of rapid urbanization, unemployment, demand of services, etc., but also with troubles affecting the rural areas which have been emptied: they are aging and they need special attention in terms of services offered to the population and economic activities to be established. Moreover, the general enrichment of a young middle class, seeking for culture and creative supply, created a new (mainly internal) demand for the Travel and Hospitality industries. If we focus on China, we can appreciate an incredible growth in this sector, in which, since 2010, the annual growth has been over the $20 \%$, while in 2017 , the growth has been just of $12 \%$ (which, in comparison with other countries all around the world, can be considered very high) [2]. Moreover, if the forecasts become true, in 10 years, China will overtake the USA in terms of GDP, investments and domestic spending for tourism, revealing the trust that China and Chinese investors have in the hospitality industry.

\subsection{Sustainability, Tourism and Hospitality}

All these facts/forecasts are extremely relevant if we consider the tendency of tourism to impact territories and societies both negatively when it is badly designed, and positively, when it becomes a force that promotes sustainable activities and relations among communities, people and the environment.

In fact, the relevance of this phenomenon lead the United Nations to decide to dedicate the International year of 2017 to Sustainable Tourism for Development, with the goal to encourage initiatives to sensitize public opinion, policy makers, managers and citizens on the importance to think about sustainable solutions for touristic activities. Moreover, the fact that the International Year was dedicated to "Sustainable Tourism for Development" underlines the role that tourism and hospitality can have in promote the development of communities, natural environments and cultural heritage. In fact, there are several cases in which the direct management of tourism activities, operated by local communities, can lead to very interesting forms of sustainable development that deserve attention from the entire tourism sector and institutions $[5,6]$.

Several authors and studies agree on the fact that speaking about the concept of sustainability related to the sector of tourism and hospitality is very difficult and complex [7]. This is due to several reasons that can be resumed as follow:

- Different levels: in addition to being complex, such as the concept of "sustainability" itself, the tourism sector is extremely vast and contains complex phenomena, which take place at different levels [7]. For these reasons, is very important to study the micro-level of socio-demographic characteristics in order to understand the practices that make tourism a real activity promoting sustainability for the development of territories and communities [8].

- Different needs: the tourism sector is very different from the general reality [9]. This is because the complexity of tourist and hospitality services is much greater than normal services; moreover, the needs and demands of users in holiday moments are different from normal.

- Interests: addressing the issue of sustainability in tourism and hospitality highlights various aspects, whose reading can vary greatly based on the economic and political interests involved [10].

- Supply chain: the long chain of services and products makes the tourism sector difficult to assess in terms of sustainability and to take some indicators that can evaluate the whole process [10].

\subsection{Chinese Tourism: Policies and Theoretical Background}

According to the framework outlined so far, the policies for the development of tourism in China are the object of several strong discussions about the social-economic balance between costs and benefits. Touristic policies are the center of several analyses and studies that aim to evaluate their impact in the social and cultural realities of the country, especially in poorer rural areas [11-13]. In fact, there is also the relevant consideration about the impact of tourism on regional disparities, which, in China, 
are strongly perceived: inbound tourism balances the regional economic disparities and narrows the regional economic gap [14]. Nevertheless, the impact of tourism is wider, reaching, of course, also urban realities, and thus penetrating the society in a way that has led some authors to theorize that this phenomenon is even reconfiguring the traditional Chinese values (terminal, "strumental" and interpersonal values) [15].

In the wide range of touristic supplies, the two most important typologies presented in the Chinese market are: one related with naturalistic purposes and one related with historical and cultural heritage $[16,17]$. Both of them are linked to some main issues that the Chinese Government wants to face in the next few years:

- Social problems: Chinese policies are addressed to promote the possibility of offering equal opportunities to all the citizens. The key concepts of these policies could be outlined as: ageing, inoccupation, balance regional and rural-urban development, improvement of live hood, communitarian belonging, deepening reform of the household registration system. The study of Zhuang, Hong and Suqiu [18] demonstrates that the increase of tourism improves the social fabric in terms of a larger demand of equal distribution, willingness to participate in the public management and interest in public business. As already demonstrated by the authors, thanks to design solutions based on landscape patterns (and not only land use) participation and social inclusion can have a deeper and more positive impact on the coexistence between villagers and the growing tourism industry and on rural village regeneration [19].

- Economy opportunities: agriculture, the driving force of China's economy until a few decades ago, has undergone a major mechanization phenomena and its role in the Chinese economy has been displaced in many areas of the country by the industrial and innovation sectors, whose incredible developments have led China to be among the world leaders in these fields.

- Heritage: even if the concept of heritage preservation and its "authencity principles" have been exported from western countries, [20] cultural heritage is assuming a key role in the tourism industry. Its importance is not only seen in an economic perspective, since it plays a significant role in promoting identity and cultural diversity, enhancing the sense of community and belonging to improve the quality of life. Previous research by the authors [19] highlights as, landscape elements, such as ancient relics, ruins, and historical heritage, mediate the relations between human beings and the environment contributing to the human well-being. Anyway, for contemporary social changes, within this panorama of Chinese practice, the preservation of spiritual cultural heritage referred to religious tourism is often to be ascribed mainly to business purposes [21,22]. The promotion of cultural heritage policies (referred to artistic, architectural, urban, landscape and natural goods) takes place both in rural and in urban areas [23].

- Land sustainability: the protection of land and environment means, in the medium and long term, a better quality of life for people but also preservation of the rich Chinese rich biodiversity and of the variety of environmental richness, considered an unlosable natural heritage.

For these four main reasons, the Chinese Government introduced the topic of Sustainable Tourism as a strategy to reach the goals proposed in the Sustainable Development Plans, as the 13th five-year plan for economic and social development of the People's Republic of China (2016-2020), where the word "tourism" appears 27 times [24].

So, policies and actions for the implementation of sustainable practices in tourism are becoming real responses to the challenges moved by the contemporary environmental and social crisis. And this is true both focusing in the Chinese reality, but also with a wider sight over the international panorama of tourism sector $[25,26]$.

There is also a relevant aspect because we should consider tourism and its relations with the design practice: as the Pritzker prize to Wang Shu in 2012 and many other international awards to Chinese architects demonstrated, design in this country is going through an important and interesting phase of debate and innovation, which deals with tackling issues that match very well with the tourism 
sector: the rediscovery of the historical and cultural heritage as good for the promotion of healthy local identity and tourist attractiveness [12,13]; the enhancement of naturalistic and landscape resources [19]; attention to the rural realities, richer in collective memory in terms of materials, skills and local culture.

\subsection{Gaps in the Current Academic Literature}

According to the above-expressed state of the art, these are the main issues that emerge in the literature framework:

- tourism is a sector that must be studied to understand its potentialities and risks, since its impact on the territories (communities and environment) is extremely relevant;

- the concept of "sustainability" in tourism is difficult to define and to measure in practice, but an effort to understand how the Chinese polices move toward this direction is needed, since the dimensions of this sector in China;

- the tourism and hospitality sector in China is managed at different political levels by several documents, laws and policies that regard different issues, among the other infrastructure and territories, equalities and rights, culture and history. Clarity on the existing policies and on their characteristics in terms of "sustainability" promotion is needed;

- contemporary design practice in China is active on topics that are relevant for the tourism sector. Understanding which issues count with matches between policies and practice and which have the highest opportunities for development can become relevant information for policy makers, managers, destinations and designers.

Based on the this framework, the authors want to focus their attention on some gaps that can be gathered in two main fields: (1) one regarding the academic literature about the relations between sustainability, policies and tourism in China and (2) one regarding the practice and its relations with public policies and tourism in China. Thus, the research expects to contribute to both fields to solve these doubts and to fill the gaps.

Based on the analysis of the current academic literature and of the emerging topics, it can be highlighted that some lacks exist, in particular regarding the academic literature about sustainable tourism, public policies and design, and regarding the ability of the tourism sector to receive and implement public policies. In fact, to the best of our knowledge, according to the existing academic literature, it is not precisely stated which among the documents on Chinese public policies are the most relevant and how much its guidelines are consistent with the indications for sustainable development as expressed by an internationally recognized document, such as the Sustainable Development Goals by United Nations. In fact, this paper was designed to (1) provide indications that national governments must follow to draft national guidelines and (2) capture the vast panorama of sustainability. This serves to clarify the current role of Chinese policies in terms of tourism and how China is moving towards tourism that can be considered "sustainable".

Furthermore, in the practice of tourism and hospitality in China, some aspects still emerge as uncertain and require a more in-depth analysis for the interpretation of the phenomena. Among all the guidelines that the Chinese government produced to encourage tourism, which is already recognized as a key sector for the development of a country, some of them will be more successful in being implemented by practice and some others will be less successful. This means that tourism practices are moving in some directions encouraged by politics, while other directions are not yet consolidated as relevant sectors. This issue can offer important fronts for initiatives that can receive more attention from the local and central governments. This aspect is even more relevant if we consider the marginal role played by the private sector in Chinese entrepreneurship. As highlighted again by Legrand et al. [9], the private sector plays a fundamental role in managing the tourism sector and it is precisely this role that takes on different characteristics in a country like China.

Globally, this research has the ambition to focus on the level of Chinese public policies, to understand both how they are receptive of the sustainable development instances, as internationally 
expressed, and how effective they are, being adopted by the contemporary design practice and management. Thus, in addition to covering some theoretical and practical gaps, as stated, this research also aims to be a theoretical base that open development opportunities for the implementation of decision-making tools, such as, for example, a tool-kit that could support policy-makers, managers, designers and even citizens to better understand their role in the touristic sector, to take decisions and to be better involved in the practice (refer to Section 5.4. Limitations and Future Research Directions).

\section{Materials and Methods}

For the reasons just expressed, two aspects to be treated in this panorama were considered relevant: (1) to clarify the concept of "sustainability" in the tourism policies by directly analyzing the public policies that often, more than "sustainable development oriented" can be defined as "economic-growth oriented" [25] and (2) the effectiveness of the policies themselves and their impact on the practice. The research has therefore set itself the goal of responding to two main research questions: (1) how much can the Chinese policies for the development of tourism be considered "sustainable" and (2) how many of these policies considered "sustainable" are actually applied to real cases.

\subsection{Methodological Framework}

To answer these research questions, this study was structured into two main phases (Figure 1).

- $\quad$ Phase 1: focused on the study of Chinese governmental policies and their characteristics of sustainability. To develop this first phase, only textual material was used, namely: (1) the official documents of the Chinese government regarding tourism policies (both in Chinese and English); (2) scientific articles and recent reports analyzing these Chinese documents, [26-28] in order to have also a broader overview provided by independent sources (the use of independent sources reflects the necessity to have objective points of view on practices in China and to corroborate the veracity of government policies); and (3) official documents by the United Nations about the Sustainable Development Goals (SDGs) in order to have an internationally recognized frame of sustainable practices. The research then compared Chinese political lines with the international practices expressed by the UN [29].

- $\quad$ Phase 2: The second phase of the research focused on the search for government policies (those emerged as "sustainable" in the Phase 1), in contemporary tourism practice. To do this, thirty projects for the hospitality and tourism industry carried out in China after 2013 were analyzed thanks to textual and graphic documents. The analysis consisted in mapping (1) which sustainable policies of the Chinese government have been adopted in each project and (2) how they became a reality through design solutions. The choice of the thirty cases was based mainly on the need to proportionally represent the different trends in the construction of the Chinese tourism sector from 2013 and on the availability of material to be analyzed. 
The Outline for National Tourism and Leisure 2013-2020 (ONTL)

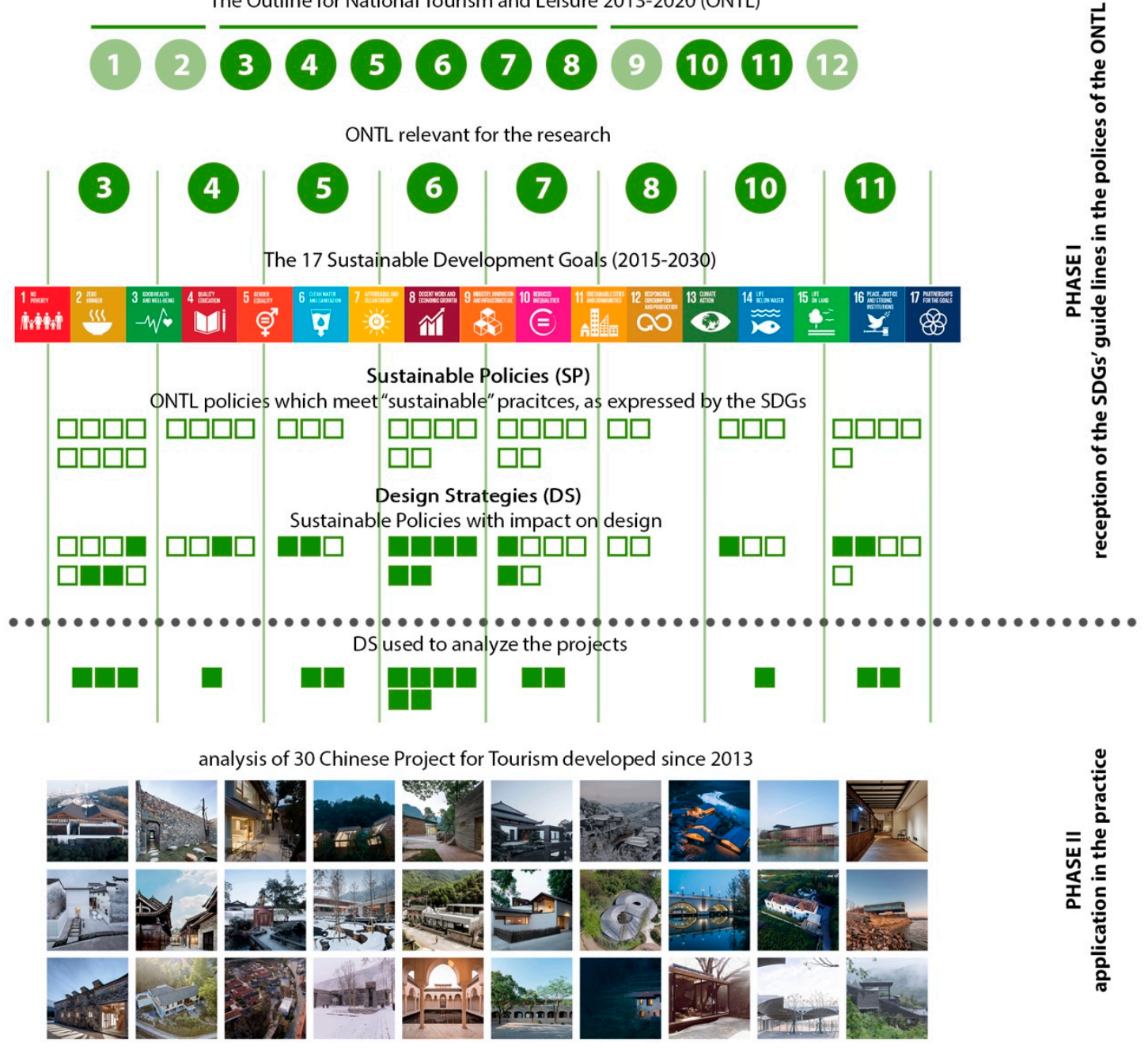

Figure 1. Research process diagram with reference to the phases and pictures of the 30 cases studies. ONTL, Outline National Tourism and Leisure: it is the document analysed during the research and constituted by 12 main points; PS, Planning Strategies: are the guidelines for tourism activities, expressed in the different ONTL points; DS, Design Strategies: are those Planning Strategies (PS) that have a direct impact on the design of the built environment; SDGs, Sustainable Development Goals: are the internationally recognized goals, expressed in the 2030 Agenda for Sustainable Development of the United Nations.

\subsection{Research Structure}

\subsubsection{Phase 1.1: Choice and Critical Analysis of Documents}

Starting from the need to evaluate the Chinese Public Policies on tourism, the documents to be analysed were chosen according to the relevance they have on the theme of tourism development and on the impact they have in the whole country. As observed in the previous discussion on the review of the art of tourism in China, several documents released by the Chinese Government deal with the theme of tourism. This is attributable to the fact that tourism is a human activity extremely impactful in the economic, cultural and social fields. For this reason, it is natural that the touristic issues appear in several political documents. Despite this variety in the documents released, the ONTL is the document that better recaps the whole point of view of the Chinese Government about tourism development. The ONTL contains the guidelines expressed in all the other general and broad planning documents, grouping the guidelines into a clear organization based on the 12 points. 
As can be seen below in the description and discussion of this document, some of the twelve points do not relate with the aims of the research. For this reason, in order to facilitate an in-depth focused analysis of the other more relevant points: 1 (Guiding Principles), 2 (Objectives), 9 (Strong Leadership and Organization) and 12 (Strong Supervision \& Regulation) were removed from the following analysis.

\subsubsection{Phase 1.2: Definition of the Sustainable Practices (SP) by Punctual Correlation ONTL—SDGs}

All the remaining ONTL were analyzed to mine the sustainable practices, as expressed by the SDGs, present in each point of the Chinese document. This process allowed the authors to extrapolate the Chinese policies that can be considered "sustainable" and that are called in the article "Sustainable Practices" (SPs). The result of this procedure, presented in the following section of results (Section 3), shows which SPs are present in the ONTL.

\subsubsection{Phase 1.3: Definition of the Design Strategies (DS) by Assessment of SP Impact on the Built} Environment

This third step concludes the first part of the research, which refers to the study of ONTLs and their relationships with SDGs. In particular, this assessment allows to understand which SPs contain guidelines that impact the design practice. This procedure was based on the clear declaration of direct influence on the built environment. All the SPs that clearly indicate an intervention on landscape, infrastructures, urban settlements, etc., have been considered valid. The outcome of this step is a set of Design Strategies indicated in the paper as (DS), and they refer to the SPs with impact in the design practice. On the contrary, the SPs that indicate strategy related just to financial investments, management of human resources, etc., were not considered, in order not to blur the evaluation of the cases, even if the authors are aware that these SPs could have indirect or long-term effects on the built environment. Since the DS are those ONTL practices characterized by features of "sustainability" and "design", the DS become those elements that indicate the practice's receptiveness of sustainable policies for tourism.

\subsubsection{Phase 2.1: Definition of the Case Studies}

This fourth step is the beginning of the second phase, which analyses the impact that the ONTLs, have on architecture and construction practice in China. For this reason, thirty case studies were selected to evaluate the presence of the Design Strategies (DS) in the design practice. In fact, the DS were used as indicators to evaluate the tendency of the ONTL polices to be adopted by the practice. The number of projects was chosen based on comparisons with similar studies and based on the number of projects with complete and accessible information available. Since this research studies the ONTL, which were released in 2013, for the accuracy of the analysis, the selected projects were realized after 2013 and have a direct impact on hospitality and on the cultural activities which can directly influence local tourism phenomena. Another aspect taken into consideration was the geographical distribution, with the aim to obtain as much uniformity as possible throughout China, in order to cover the various social, cultural and legislative realities that compose this complex country. The decision to study the effectiveness of the policies through case studies derives from one of the main strengths of case studies strategies, the "Focus on the embeddedness of the case in its context" and "Capacity to explain causal links" as Groat and Wang highlight in their book Architectural Research Methods [30] Moreover, according to the citation by Robert Yin "A case study is an empirical inquiry that investigates a contemporary phenomenon within its real-life context, especially when the boundaries between phenomenon and context are not clearly evident." [30] (p. 441), the choice of case studies methodology to answer the research questions seems effective for an issue not so clearly defined as this one related to sustainable tourism in the Chinese context. 


\subsubsection{Phase 2.2: Analysis of the Projects, through DS, and Comparisons}

Each of the 30 selected projects has been studied using available published material (the sources are indicated for each project), such as textual, video and graphic sources: description by the architects, description by architectural critics, photographs or drawings. This allowed to understand the reasons, methods and objectives of each project and to analyze them according to the DS as previously defined. Here, it is necessary to highlight how research does not want to measure the effects of a policy, but rather whether policies, in the form of design strategies, are present or not in a number of realized projects. For this reason, using DS as an indicator is absolutely in line with the logic of this research. In fact, for each selected project, it was observed whether each DS is present and, if so, how many design choices contribute to this strategy. This indicates the presence of policies in the form of design strategies, in the design practice. To ensure that the DS's presence or absence is effective, a sufficiently large number of documentary resources (at least three sources) were used to study the project, in order to triangulate the basic information. Once the DSs appearing in each project were deduced, a comparison was made among the results of all the projects. Then, the DSs were grouped by logical area, which made it possible to summarize the considerations according to semantic/design clusters that led to the elaboration of the final considerations.

\section{Results of Phase 1: Chinese Policies and Sustainability}

In order to understand which document better covers the Chinese public policies for the development of tourism and based on the considerations expressed by several documents and scientific articles [31-38] about Chinese Public Policies and by the World Tourism Organization (UNWTO), it was decided to study the following documents:

- Chinese 13th Five-year Plan (2016-2020): adopted in March 2016 by the People's National Assembly of China, which explains the goals and the strategies for their implementation in the period 2013-2020. Since 1953, the Chinese Government, through its central assembly, releases every five years, this type of programmatic document [24].

- New urbanization plan for 2014-2020: presented in March 2014 by the Chinese Government. It is the first Chinese official framework for national strategies for urbanization. This is a document intended to spur economic growth, aligned to a sustainable method of urbanization, attentive to air quality, lifestyle and environmental matters [39].

- Regulations on Paid Annual Leave for Employees: adopted on December 2007 during the meeting of the Executive Meeting of the State Council. This is a regulation for the safeguard of the employees to take rest and leave. The policies presented in this document, even if focused more on job management, have had a relevant impact on the tourism industry, since the possibility to leave the job for a few days was granted [40].

- Outline for National Tourism and Leisure: approved by the State Council (the Chinese highest level of government) in February 2013. According to the official statement, these outlines aim to meet "people's growing needs in tourism and leisure, promote the healthy development of the tourism and leisure industry, and build a Chinese-style national tourism and leisure system" [41-44].

The analysis of these documents was conducted (1) directly, through the study of the English official versions and the Chinese official version of the documents (with the comparison reading among the two versions by a Chinese-speaking scholar from Tongii University of Shanghai) and (2) indirectly through the study of commentary articles from a scientific database and official UNWTO press releases [41,43].

Here are proposed some of the most relevant comments:

- The UNWTO, asserts that the ONTL represent the efforts that China is working to find proposals for sustainable tourism for development and that it is totally in line with the "UNWTO's historical document, the Tourism Bill of Rights, released in 1985 as well as the UNWTO's Global Code of Ethics for Tourism, adopted by the United Nations in 2001" [44]; 
- According to the same document, “China's New Landmark Tourism Strategy: The Outline for National Tourism and Leisure (2013-2020)" (ONTL), the whole Country will live a complete redefinition of tourism development and management, in particular, taking advantage of the benefits of the hospitality activities in impacting the economic, socio-cultural and environmental fields. These guidelines represent a "roadmap for restructuring the current paid leave system across China and outlines the technical multi-sector aspects of creating a more fruitful environment for sustainable tourism development and management in the country" [44]. In this way, the public policies presented in these guidelines (1) address the issue of holiday flexibility for workers, but at the same time (2) they mobilize a wide variety of economic sectors, inviting them to consider their actions according to the development of tourism;

- Again, "China's new national tourism strategy set to increase outbound tourism" [43], the UNWTO Secretary-General Taleb Rifai comments: "This document calls on a variety of sectors to strategically consider their actions in view of the development of tourism; it is another proof that China fully understands that sustainable tourism growth requires cross-cutting policies at a national level".

The direct reading of all these documents and the study of articles and an analysis shows that the guidelines present in the ONTLs, whether they are for management or design, can be considered sufficiently representative of the Public Policies provided by the Chinese Government for the issues of tourism development. For this reason, the authors chose to study exclusively the Outlines for National Tourism and Leisure, considering it completely representative.

\subsection{ONTL: Outlines for National Tourism and Leisure}

To study the Public Policies presented in the ONTL, the whole document was analysed. This document is composed of 12 points describing the outlines and grouped into three main themes: (1) Guiding Principles and Objectives, (2) Major Tasks and Measures and (3) Organization and Implementation. According to the relevant issues expressed in the commenting documents and the contents of each point, the authors decided to proceed with the removal of those points, which clearly do not indicate strategies directly related to the built environment. Thus, the authors decided to eliminate the introductory and the final points, which do not contain significant contributions to the research (namely points 1, 2, 9 and 12 of the ONTL). For completeness and in order to have a general overview of the contents and subsequent analyses, the Outline for National Tourism and Leisure 2013-2020 (ONTL) points are fully reported in the Appendix A, with some comments and considerations by the authors, useful to the development of the research.

\subsection{Punctual Correlation of the ONTL with the 17 SDGs and Appraisal of Their Impact on the Built Environment}

In this step, all the outlines were analysed through the lens of the indications given by the seventeen SDGs. This means that the authors, with the support of the existing literature $[45,46]$, looked for sustainable policies, as expressed by the United Nations' SDGs, in all the strategies stated point by point in the ONTL. The resulting policies were defined as Sustainable Policies (SP) as listed in the following tables (Tables 1-8). Moreover, for each of these SPs, the authors considered those that have clear influence in the design practice; in other words, those strategies that have impact in the Built Environment. These specific strategies have been defined as Design Strategies (DS).

In the following tables, all the considerations about the relations between ONTL, sustainable policies (expressed through the SDGs) and design practice are presented. Each table presents the results for one single ONTL point considered relevant for the research. The table indicates the planning strategies (PS) expressed by the specific outline, relating them with the respective SDG and eventually, indicating if the PS impacts in the Built Environment. In this case, the last column is filled with a code that indicates the DS. This code will be used in the following steps of the research to relate DS and design solution in the practice. The code is structured as follow: the first number indicates number of the ONTL key point; the second number indicates the SDGs goals under which the design strategy (DS) 
apply solutions or improvement; the third number, if available, is a progressive number indicating that under the same ONTL key point and the same SDG, there are many design strategies that can be applied and implemented. As an example: the code DS 3.9 (see Table 3) indicates that the code is related to point 3 of the ONTL and Goal 9 of the SDGs and so forth for all the DS codes.

Table 1. ONTL 3. Sufficient time for national tourism and leisure.

\begin{tabular}{ll}
\hline \multicolumn{1}{c}{ SGD } & \multicolumn{1}{c}{ SP } \\
\hline $\begin{array}{l}\text { GOAL 3: Good Health and } \\
\text { Well-being }\end{array}$ & To ensure rest days for employees during their working periods. \\
\hline GOAL 4: Quality Education & School holidays \\
\hline $\begin{array}{l}\text { GOAL 8: Decent Work and } \\
\text { Economic Growth }\end{array}$ & $\begin{array}{l}\text { The government, organizations and enterprises are obliged to } \\
\text { provide paid holidays and flexible working schedules for their } \\
\text { employees. }\end{array}$ \\
\hline $\begin{array}{l}\text { GOAL 9: Industry, Innovation } \\
\text { and Infrastructure }\end{array}$ & $\begin{array}{l}\text { Prioritize in infrastructure for tourism and spaces destined to } \\
\text { hospitality services while it guaranteed their accessibility. }\end{array}$ \\
\hline GOAL 10: Reduced Inequality & $\begin{array}{l}\text { Fundamental rights such as having rest days must be respected } \\
\text { for all the population. }\end{array}$ \\
\hline $\begin{array}{l}\text { GOAL 11: Sustainable Cities } \\
\text { and Communities }\end{array}$ & $\begin{array}{l}\text { Historical places will be closer and accessible to citizens and } \\
\text { communities. }\end{array}$ \\
\hline $\begin{array}{l}\text { GOAL 12: Responsible } \\
\text { Consumption and Production }\end{array}$ & $\begin{array}{l}\text { A sustainable supply of tourism products and services will be } \\
\text { provided. }\end{array}$ \\
\hline $\begin{array}{l}\text { GOAL 16: Peace and Justice } \\
\text { Strong Institutions }\end{array}$ & $\begin{array}{l}\text { The government and official institutions are responsible for } \\
\text { supervising the achievement and correct implementation of the } \\
\text { suggested tools. }\end{array}$ \\
\hline
\end{tabular}

Table 2. ONTL 4. Better environment for national tourism and leisure.

\begin{tabular}{lll}
\hline \multicolumn{1}{c}{ SGD } & \multicolumn{1}{c}{ SP } & DS \\
\hline GOAL 4: Quality Education & Education tours will be introduced for schools and their students. \\
\hline $\begin{array}{l}\text { GOAL 8: Decent Work and } \\
\text { Economic Growth }\end{array}$ & $\begin{array}{l}\text { Employees will be provided with tourism and leisure by the } \\
\text { enterprises. }\end{array}$ \\
\hline $\begin{array}{l}\text { GOAL 9: Industry, Innovation } \\
\text { and Infrastructure }\end{array}$ & $\begin{array}{l}\text { Infrastructure for tourism transport should be incorporated to the } \\
\text { public transport system. }\end{array}$ \\
\hline \multirow{3}{*}{ GOAL 10: Reduced Inequality } & $\begin{array}{l}\text { Free public entrance to museums and sites for patriotic education } \\
\text { will be offered. }\end{array}$ \\
\cline { 2 - 3 } & $\begin{array}{l}\text { The ticket prices for recreation sites will be reduced and will } \\
\text { benefit different population groups. }\end{array}$ \\
\hline
\end{tabular}

Table 3. ONTL 5. Improved infrastructure for national tourism and leisure.

\begin{tabular}{llc}
\hline \multicolumn{1}{c}{ SGD } & \multicolumn{1}{c}{ SP } & DS \\
\hline \multirow{2}{*}{$\begin{array}{l}\text { GOAL 9: Industry, Innovation } \\
\text { and Infrastructure }\end{array}$} & $\begin{array}{l}\text { Leisure space will increase by building city parks, recreation belts } \\
\text { around metropolis and for residents in villages and towns. }\end{array}$ & 5.9 .1 \\
\cline { 2 - 3 } & $\begin{array}{l}\text { Infrastructure such as family inns, hotels and motels will be } \\
\text { promoted. }\end{array}$ & 5.9 .2 \\
\cline { 2 - 3 } & Ports for aquatic mobility will be supported. & 5.9 .3 \\
\hline GOAL 10: Reduced Inequality & To ensure accessibility to public spaces. & 5.10 .1 \\
\cline { 2 - 3 } & Implement information services for the disabled population. & 5.10 .2 \\
\hline GOAL 15: Life on Land & Parks, afforested lands and public leisure spaces will be protected. & \\
\hline
\end{tabular}


Table 4. ONTL 6. Product development and activity organization of national tourism and leisure.

\begin{tabular}{lll}
\hline \multicolumn{1}{c}{ SGD } & \multicolumn{1}{c}{ SP } & DS \\
\hline $\begin{array}{l}\text { GOAL 3: Good Health and } \\
\text { Well-being }\end{array}$ & $\begin{array}{l}\text { Tourism and leisure products that improve life quality and } \\
\text { physical health will be developed. }\end{array}$ & 6.3 \\
\hline \multirow{2}{*}{ GOAL 4: Quality Education } & Tourism activities will promote fine traditional culture. & 6.4 .1 \\
\cline { 2 - 3 } & $\begin{array}{l}\text { Cultural recreation and popular science education will be } \\
\text { included in the tourism field. }\end{array}$ & 6.4 .2 \\
\hline $\begin{array}{l}\text { GOAL 9: Industry, Innovation } \\
\text { and Infrastructure }\end{array}$ & $\begin{array}{l}\text { Research and development of tourism infrastructure and } \\
\text { equipment will be intensified. }\end{array}$ & 6.9 \\
\hline \multirow{2}{*}{ GOAL 10: Reduced Inequality } & $\begin{array}{l}\text { Tourism will be offered for different groups of people, including } \\
\text { the people with disabilities. }\end{array}$ & 6.10 .1 \\
\cline { 2 - 3 } & $\begin{array}{l}\text { The tourism services will be provided in the rural and urban } \\
\text { context. }\end{array}$ & 6.10 .2 \\
\hline $\begin{array}{l}\text { GOAL 12: Responsible } \\
\text { Consumption and Production }\end{array}$ & $\begin{array}{l}\text { Services and products that look after health and physical care and } \\
\text { that include cultural performance will be offered. }\end{array}$ & 6.12 \\
\hline GOAL 15: Life on Land & The rural spaces for vacation will be promoted. & 6.15 \\
\hline
\end{tabular}

Table 5. ONTL 7. Well-developed public services for national tourism and leisure.

\begin{tabular}{|c|c|c|}
\hline SGD & SP & DS \\
\hline \multirow{2}{*}{$\begin{array}{l}\text { GOAL 3: Good Health and } \\
\text { Well-being }\end{array}$} & $\begin{array}{l}\text { Information regarding safety risks on tourism and leisure } \\
\text { destinations will be reinforced. }\end{array}$ & 7.3.1 \\
\hline & Improve the rescue system for tourists and other emergencies. & 7.3.2 \\
\hline GOAL 4: Quality Education & $\begin{array}{l}\text { To improve the direct relation between education models and } \\
\text { vocational education with the tourism and leisure industry. }\end{array}$ & \\
\hline $\begin{array}{l}\text { GOAL 6: Clean Water and } \\
\text { Sanitation }\end{array}$ & Hygiene in tourism will be enhanced. & \\
\hline $\begin{array}{l}\text { GOAL 8: Decent Work and } \\
\text { Economic Growth }\end{array}$ & To train tourism professionals to offer qualified services. & \\
\hline \multirow{3}{*}{$\begin{array}{l}\text { GOAL 9: Industry, Innovation } \\
\text { and Infrastructure }\end{array}$} & $\begin{array}{l}\text { Tourism information centers in public spaces and expressway } \\
\text { service areas will be built. }\end{array}$ & 7.9.1 \\
\hline & The road sign system will be improved. & 7.9.2 \\
\hline & $\begin{array}{l}\text { The tourism transport services in railway, highway, waterway } \\
\text { transport and civil aviation will be improved. }\end{array}$ & 7.9 .3 \\
\hline GOAL 10: Reduced Inequality & Ensure barrier-free services for population with disabilities. & \\
\hline
\end{tabular}

Table 6. ONTL 8. Enhanced service quality in national tourism and leisure.

\begin{tabular}{|c|c|c|}
\hline SGD & SP & DS \\
\hline \multirow{2}{*}{$\begin{array}{l}\text { GOAL 12: Responsible } \\
\text { Consumption and Production }\end{array}$} & $\begin{array}{l}\text { The application and accomplishment of quality standards of } \\
\text { national tourism and leisure will be supervised. }\end{array}$ & \\
\hline & Promote honest operation and discipline in the tourism industry. & \\
\hline \multirow{2}{*}{$\begin{array}{l}\text { GOAL 16: Peace and Justice } \\
\text { Strong Institutions }\end{array}$} & $\begin{array}{l}\text { Across sectors and regions the communications and coordination } \\
\text { will be strengthened to protect the interest of consumers } \\
\text { against fraud. }\end{array}$ & \\
\hline & $\begin{array}{l}\text { To protect the legitimate rights and interests of operators and } \\
\text { customers in the tourism and leisure market. }\end{array}$ & \\
\hline
\end{tabular}


Table 7. ONTL 10. Sound planning and guidance.

\begin{tabular}{|c|c|c|}
\hline SGD & SP & DS \\
\hline $\begin{array}{l}\text { GOAL 9: Industry, Innovation } \\
\text { and Infrastructure }\end{array}$ & $\begin{array}{l}\text { The urban and rural planning will have consideration to lands for } \\
\text { tourism and leisure, while improving their layout. }\end{array}$ & 10.9 \\
\hline $\begin{array}{l}\text { GOAL 12: Responsible } \\
\text { Consumption and Production }\end{array}$ & $\begin{array}{l}\text { Each region will be advised to enhance its own resources and to } \\
\text { develop contextualized tourism and leisure sectors and plans. }\end{array}$ & \\
\hline $\begin{array}{l}\text { GOAL 16: Peace and Justice } \\
\text { Strong Institutions }\end{array}$ & $\begin{array}{l}\text { Social and economic development plans will incorporate national } \\
\text { tourism and leisure. }\end{array}$ & \\
\hline
\end{tabular}

Table 8. ONTL 11. Vigorous policy support.

\begin{tabular}{llc}
\hline \multicolumn{1}{c}{ SGD } & \multicolumn{1}{c}{ SP } & DS \\
\hline GOAL 4: Quality Education & $\begin{array}{l}\text { Non-governmental leisure facilities destined to museums, } \\
\text { academies of art and sports centers will be encouraged. }\end{array}$ & 11.4 \\
\hline $\begin{array}{l}\text { GOAL 8: Decent Work and } \\
\text { Economic Growth }\end{array}$ & $\begin{array}{l}\text { The Government will support with specific policies the micro, } \\
\text { small and medium-sized enterprises related to tourism sector. }\end{array}$ & 11.8 \\
\hline $\begin{array}{l}\text { GOAL 9: Industry, Innovation } \\
\text { and Infrastructure }\end{array}$ & $\begin{array}{l}\text { The Government will gradually increase the financial input into } \\
\text { public works and service infrastructure in support of tourism and } \\
\text { leisure activities. }\end{array}$ \\
\hline $\begin{array}{l}\text { GOAL 12: Responsible } \\
\text { Consumption and Production }\end{array}$ & $\begin{array}{l}\text { High-quality tourism and leisure products will be developed with } \\
\text { investment. }\end{array}$ \\
\hline $\begin{array}{l}\text { GOAL 17: Partnerships to } \\
\text { achieve the Goal }\end{array}$ & $\begin{array}{l}\text { Non-governmental sectors will be encouraged to invest in tourism } \\
\text { and leisure facilities. }\end{array}$ \\
\hline
\end{tabular}

\section{Results of Phase 2: Public Policies in Practice}

The number of projects to study has been defined by comparison with similar researches and thirty cases have been considered a suitable number of projects to study the phenomenon. The authors chose these projects according to the availability of describing the material within the considered period (after 2013). Moreover, the selected projects have a direct impact on tourism, on hospitality and on cultural activities that can directly influence local tourism phenomena. Yet, they cover a wide geographical distribution throughout China in order to cover the various social, cultural and legislative realities that compose this complex country. Finally, the context was also taken into consideration, trying to maintain a balance between different contexts, in function of the proportion among the actually realized projects in China. [27] Another remarkable element for the choice of the cases was the necessity to represent their relevance in preserving the identity and cultural heritage, their social and economic impact. These categories and functions are (1) services to the local population (shop, multifunctional complex, etc.); (2) development of business and local entrepreneurship (hotel, restaurant, bar, guesthouse, etc.); (3) development of cultural activities (cultural center, museum, library, art gallery, etc.); (4) development of tourism facilities and services (information center, visitor center, etc.); (5) development of infrastructure for tourism (tourist terminal, etc.). Moreover, attitudes toward the heritage are relevant in sampling the phenomenon: reconstruction, refurbishment, restoration, etc.

Each project was studied through graphical material and written descriptions available in publications and online platforms. Below is the list of the 30 case studies analyzed to develop the research and that are detailed in the Appendix B. The four case studies, which are presented in detail, are highlighted in bold. (1) A. Mono Coffee Shop; (2) Anji Erlu Resort; (3) Bamboo Craft Village; (4) Chatouya Visitor Center; (5) Courtyard-Wayuan; (6) Dafa Canal Tourist Information Center; (7) Hakka Indenture Museum; (8) Hangzhou Senbo Resort; (9) History Museum of Qifeng Village; (10) Hiuxin Retreats; (11) Hotel of Septour; (12) Island Conference Hotel; (13) Jianamani Visitor Center; (14) Kangka Zhouzhuang Tourist Resort Aquatic Club; (15) Library on the Quay; (16) Lost Villa Boutique Hotel in Yucun; (17) M2 Tourist Port at Bai Lianjing; (18) Mica-Bar; (19) Nanxianglou Art Hotel; (20) Ruralation 
Shenaoli Library; (21) Rustic Charm Inn; (22) Shaoxing Hotel; (23) Shaoxing Hotel reconstruction; (24) Stray Birds Art Hotel; (25) Sury Resort No.3; (26) Tourist Center of Anlong Limestone Resort; (27) Treasure House of Shanghai Himalaya Art Museum; (28) Vita-The Fortune Bridge; (29) Xinzhai Coffee Manor; (30) Yiyuan Xiaozhu.

In particular, the four projects selected to be presented in this article represent four different contemporary attitudes of Chinese design for tourism and hospitality: cultural tourism, with strong relations and impacts on tourists and local community; religious tourism, with strong relations and impacts on tourists and the local community; boutique hotel, with reduced relations between tourists and local community; regenerated buildings for hotel, with almost no direct relations between tourists and local community.

Each project is presented by the main feature, which aims to give a brief description, and by the DS which, according to the sources, are present in each project. For each design strategy were listed the design solutions adopted in the project. It is necessary to clarify that sometimes, more than one design solution can be present. In this case, they are listed as (1), (2), (3), etc. Moreover, it is also necessary to consider that, for space reasons and not to repeat several times the same information, the name of the DS was omitted and can be found in Table 1.

\subsection{Ruralation Shenaoli Library}

\subsubsection{Main Features}

The Ruralization Shenaoli Library is characterized by a strong coexistence between the local community and tourists, who can interact with the villagers in several spaces of the project, in particular, in the library and in the exhibition hall. The project addresses the issue of "authenticity criteria" which is much debated in the contemporary Chinese architectural landscape [18]. In fact, internationally, it is considered a relevant project to show contemporary architectural practice in the theme of regeneration of the Chinese historical heritage in rural areas, in order to be exhibited at the 2018 Venice Biennale at the Chinese Pavilion "Building a future countryside". [47] (pp. 112-115) [48-53].

\subsubsection{Design Strategies}

3.11: (1) A central space, the "soul salon" is preserved by the design to experience memory and the sense of belonging (of tourist and locales) to the community. (2) The close work during design and construction between the local craftsmen and the architect resulted into a valuable edification that preserves history.

- 6.3: (1) The second floor of the library offers a restaurant for guests and visitors. (2) The interior space uses contemporary design strategies and materials to offer amenity. (3) The bookstore is an ideal space for entertainment among tourists and recreation among businessmen.

- 6.4.1: (1) The project is part of an ancient village with more than 19 centuries of history. (2) The Jingsong Hall, an ancient house dating back to the late Qing Dynasty, is the core of this project. (3) The facades perform the historic texture; the traditional architectural layout and timber carving are conserved. (4) The intelligence and building methods of the local craftsmen have been strongly respected.

- 6.4.2: (1) The building contains the community library which is open to the villagers, the humanity and folkways exhibition space, and homestay for tourists. (2) The first floor of the library consists of a community library, an exhibition space and a souvenir store.

- 6.10.2: (1) The project combines the urban and rural through "urban implantations" and tries to reconcile them. (2) Communication and sharing among villagers happens mainly in the bookstore, which was designed for this aim.

- 10.9: (1) Rural tourism is reinforced with the restoration and construction of the project. (2) The project is part of the primary lanes transformation of Shenao Village. 


\subsection{Lost Villa Boutique Hotel in Yucun}

\subsubsection{Main Features}

Lost Villa Boutique Hotel in Yucun is a boutique hotel that meets the needs of an increasingly demanding rich social class, looking for luxury tourist experiences. Moreover, for this reason, the relationship with the local community is reduced and even if the possibility of interaction with the local community is taken into consideration. In fact, the Lost Villa Boutique has several spaces to host activities not exclusive for the guests: an exhibition hall, cafe and restaurant are available for guest and for the external community [47] (pp. 116-119) [54-56].

\subsubsection{Design Strategies}

- 3.11: (1) Design and construction of the complex was carried out by designers and local craftsmen to preserve the historical and cultural heritage.

- 3.12: (1) The orientation of the building is studied to match the spatial needs of the activities and the natural benefits of sunlight and ventilation. (2) External providers assisted the construction and management, providing supplies and limiting the lack of infrastructure and poor product supply. (3) The collaboration resulted in a series of sustainable furniture design (steel/wood window and door, interior plywood doors, extra-large automatic window and customized light fixtures).

- 5.9.2: (1) The hotel offers a space for leisure and recreation for the visitors. (2) The complex offers the possibility to host entire families, for example, in the independent and secluded villa.

- 6.3: (1) to improve de quality of visitors' stay, the hotel offers a loggia and a swimming pool, which buffer the site from the main road. (2) The project provides a service of leisure for tourists and visitors.

- 6.4.1: (1) The historical legacies of lands ownership in neighborhood shape the irregular boundary of the site.

- 6.4.2: (1) The hotel design includes a small exhibition area.

- 6.10.2: (1) The project attracts visitors to the rural context where its located.

- 6.15: (1) The guestrooms are located into the southern part of the building to reach panoramic scenic views of the garden. (2) The project takes advantage of the natural environment to design frames scenes and generate dynamic views from the building. (3) The design aims to achieve a dialogue between the interior details and their background natural scenery. (4) The structural system (a hybrid of masonry and wood-and-steel-trusses) preserves the rural characteristics of the place.

- 10.9: (1) One of the advantages of the project is the typical landscape condition of contemporary Chinese rural area, both heterogeneous and dynamic to be functional to the community.

- 11.8: (1) The complex includes a cafe and a restaurant to also serve the locals.

\subsection{Jianamani Visitor Center}

\subsubsection{Main Features}

Jianamani Visitor Center is a project that has been particularly successful in the international architectural media in recent years. The project, in fact, is significant in several aspects, first of all, in the fact that tourists reach the locality for reasons related to religion, which represents a first strong glue between tourists and the local community. Indeed, the Visitor Center became extremely relevant for the cultural and religious environment of the region. Moreover, the building serves both visitors and villagers by means of various public services housed in it. The project is also notable for its relevance to local identity, since, after the earthquake which hit the region in 2010, it was the first building built, long before the re-construction of the private houses. Architecturally, it represents a 
contemporary approach to architectural rural regeneration, based on the use of traditional material and techniques. Finally, the studio that designed the project won several international awards (among others, the archmarathon awards, Zumtobel, HKIA Cross-Strait Architectural Design Symposium and Awards CADA2015 Community, Culture, Religion and Recreational Projects: Gold Award) [47] (pp. 120-123) [23,57-60].

\subsubsection{Design Strategies}

- 3.9: (1) The inside of the building is laid out over two floors and accommodates several services for the community (a post office, a clinic, public toilets and a small research archive).

- 3.11: (1) Janamani has a deep significance to the Yushu community. (2) After the earthquake, the community worked together to repair Janamani before repairing their own houses and the infrastructures. (3) The project connects with place and culture. (4) Architecture achieves a sense of timelessness while also cultivating a wider social purpose.

- 3.12: (1) Socially, the project serves as a community centre for the locals. (2) The majority of the material used in the construction is wood or comes from the recycling from earthquake debris.

- 6.4.1: (1) The design of the building is based on traditional Tibetan architecture and aims to enhance the cultural aspect of the landscape. (2) The observation towers surrounding the central courtyard overlook the nearby historical landmarks. (3) The use of local stone as main construction material, recall several meanings in the Jianamani religious and historical culture. (4) The project preserves the essence of Yushu, enhancing its role as one of the most relevant religious centers. (5) The center was mainly built by local construction techniques.

- 6.4.2: (1) The roof terraces offers a view over the sacred sites nearby, in particular to the statues and the sacred picks of stone, with a strong connection of matter.

- 6.10.1: (1) The project has areas that host activities both for visitors and for the local community.

- 7.9.1: (1) The building serves as an information source for tourists.

- 11.8: (1) The stone used for the construction is the same used for the religious Mani stones. (2) More than $40 \%$ of the population live on the carving of Mani stones, producing employment opportunities to the local workers.

\subsection{Hotel of Septuor}

\subsubsection{Main Features}

Hotel of Septour represents a typology of contemporary supply for the Chinese tourism of the middle class that is demanding for experiences in natural spots. The buildings are a renovation of local dwellings and the contacts with the local community are reduced. Internationally, as Ruralation Shenaoli Library, Hotel of Septour is considered a relevant project to show contemporary architectural practice in the theme of regeneration of the Chinese historical heritage in rural areas, so as to be exhibited at the 2018 Venice Biennale at the Chinese Pavilion "Building a future countryside" [47,61].

\subsubsection{Design Strategies}

- 3.9: (1) The old timber structure works with a new one in concrete, which contributes to creating spaces for bathrooms and other facilities. (2) Around the preserved core, a series of small-scale concrete structures are built. (3) The roof of the new volumes are used as private terrace gardens for guest rooms on the second floor. (4) The new design of paths and staircases allows an intimate relation between the living spaces and the natural environment.

- 3.11.1: (1) The project offers public terraces, a meeting and dining space for the guests' interactions.

- 3.12: (1) The construction of the building contains regional materials of the area, such as stone, wood and bamboo. 
- 5.9.2: (1) A compacted village house was transformed into a spacious hotel by revising the original structure and reorganizing the width of each rooms. (2) A rounded-shape plan guest room is newly built to make the most of the backyard.

- 5.10.1: (1) The design of the hotel combines the intimacy of gardens and rooms with characteristics of opening and inviting.

- 6.3: (1) The emphasis of the design is laid on the unique experiences of entering the interior space from the exterior natural environment. (2) The height differences between volumes offer a spacious spatial sequence entering each unit. (3) The design integrates spaces for the external community, such as a cafe, meeting and dining spaces.

- 6.4.1: (1) The new building preserves the original wood-structure at the center of the complex.

- 6.10.1: (1) The design of circular pathways on the ground floor organizes continuous sequence of spaces.

- 6.10.2: (1) The hotel contributes to promoting tourism next to the Yangtze River Delta.

- 6.15: (1) The design preserves the natural characteristics of the contexts, such as orography and paths, extending them up to the interior spaces. (2) Every unit has its own garden with views, which can be enjoyed exclusively.

- 10.9: (1) The building is renovated from a local dwelling with several volumes that was traditionally built.

- 11.8: (1) The hotel reinforces the local economy through tourism by receiving visitors. (2) The project offers employment to the local villagers.

\subsection{The Results from the Analysis of the 30 Cases}

This process of analysis and synthesis, explained for these four projects, was realized for all the thirty selected cases, collecting, in this way, the design practices that match with DSs.

As described, the procedure allowed us to understand which DSs, as described in Table 1, are present in each project. During the research, it was verified whether each DS was carried out, through the presence of one or more design solutions. In case the project shows more than one solution to reach a specific DS, so that the respective DS was considered for each adopted solution. For this reason, in the final sum of all the projects, some DSs have a value of occurrences higher than 30 . In fact, for all the 30 projects, they were summed to the total number of times that each DS appears. From these values, the results expressed by Figure 2 were generated.

\begin{tabular}{|c|c|c|c|c|c|c|c|}
\hline occurrence & 51 times & 61 times & 47 times & 12 times & 9 times & 34 times & 5 times \\
\hline $\begin{array}{c}\% \text { over } \\
\text { DS 6.4.1 }\end{array}$ & $61 \%$ & $72 \%$ & $56 \%$ & $14 \%$ & $11 \%$ & $40 \%$ & $6 \%$ \\
\hline DS & 3.9 & 3.11 & 3.12 & 4.9 & 5.9 .1 & 5.9 .2 & 5.9 .3 \\
\hline 4 times & 63 times & 84 times & 25 times & 4 times & 17 times & 31 times & 4 times \\
\hline $5 \%$ & $75 \%$ & $100 \%$ & $30 \%$ & $5 \%$ & $20 \%$ & $37 \%$ & $5 \%$ \\
\hline 5.10 .2 & 6.3 & 6.4 .1 & 6.4 .2 & 6.9 & 6.10 .1 & 6.10 .2 & 6.12 \\
\hline 3 times & 5 times & 11 times & 8 times & 4 times & 27 times & 3 times & 41 times \\
\hline $4 \%$ & $6 \%$ & $13 \%$ & $10 \%$ & $5 \%$ & $32 \%$ & $4 \%$ & $49 \%$ \\
\hline 7.3.1 & 7.3.2 & 7.9.1 & 7.9.2 & 7.9 .3 & 10.9 & 11.4 & 11.8 \\
\hline
\end{tabular}

Figure 2. The 25 design strategies (DSs) (indicated with the reference number) of the ONTLs and their impact, in absolute and percentage values, on the 30 case studies. 
Thus, comparing the results of all the matches for all the projects, the authors were able to obtain data that allow to describe the impact in the constructive practice of Chinese policies for the development of sustainable tourism. This allowed us to evaluate which typologies of DSs have the main impact on the built environment. Figure 2 presents each DS, indicated by the reference number, extracted by the research and their impact on the design practice: the absolute number represents the number of times the DS appears in the thirty case studies and the percentage represents the DS in comparison with the most recurrent DS, which is the 6.4.1 (Tourism activities will promote fine traditional culture), recurring 84 times $(100 \%=84)$.

\section{Discussion of Phase 1 and Phase 2 Results}

The results of this paper offer a new paradigm for understanding China's role as a country leading practices for development of sustainable tourism and the hospital sector. This has repercussions both on the current academic literature and on the indications that policymakers, managers, investors and even citizens can follow to understand what directions Chinese tourism is taking and what their role might be in this complicated landscape. In particular, the findings highlight the relationship between governmental policies, international guidelines for sustainability and practice in the Chinese panorama of sustainable tourism for development. As demonstrated, the Chinese Government is aware of the importance of spatial design for the promotion of sustainable tourism and, in particular, of the importance of a design capable to regenerate the historical heritage of the country.

\subsection{Conclusion of Step 1: Chinese Policies and Sustainability}

As the developed analyses show, all the eight key points of the ONTL that were considered relevant for the research have some strategies clearly related to at least two Sustainable Development Goals (Figure 3). This means that the whole of the polices expressed by the ONTL demonstrates a constant attention to international sustainable guidelines. In particular:

1. Outline number 3, Sufficient time for national tourism and leisure, expresses eight goal matches, which represent the highest number of affinities with the SDGs (blue area in Figure 3). This means that Outline number 3 could be evaluated as the most "sustainable" policy, or rather the policy that proposes the more sustainable practices among all the other ONTL points. This means that this policy highlights the issue of sustainability from many points of view, dealing with rights, education, work, culture and management of the phenomenon. This is why this policy proves to be fundamental, precisely because it engages many of the actors involved in the tourism sector.

2. With regards to the relationship with design, Outline number 6, Product development and activity organization of national tourism and leisure, is the outstanding one. This Outline is the one with more affinity with design issues (green area in Figure 3) and is the Outline where up to eight Design Strategies (DS) can be defined. It is interesting to underline this outcome because Outline number 6 refers to the question of "production": an issue that is central in the UN "One Planet Travel with care", which is a program that focuses precisely on understanding and measuring the role of tourism as an activity that impacts point 12 of the SDGs, Sustainable consumption and production.

Therefore, as the main finding regarding "Chinese Policies and Sustinabiity", it can be observed that the strategies expressed by the Chinese government on the subject of tourism and hospitality are in line with the international guidelines for sustainable development and China can be considered a reference, at least in the design of sustainable policies for tourism. 


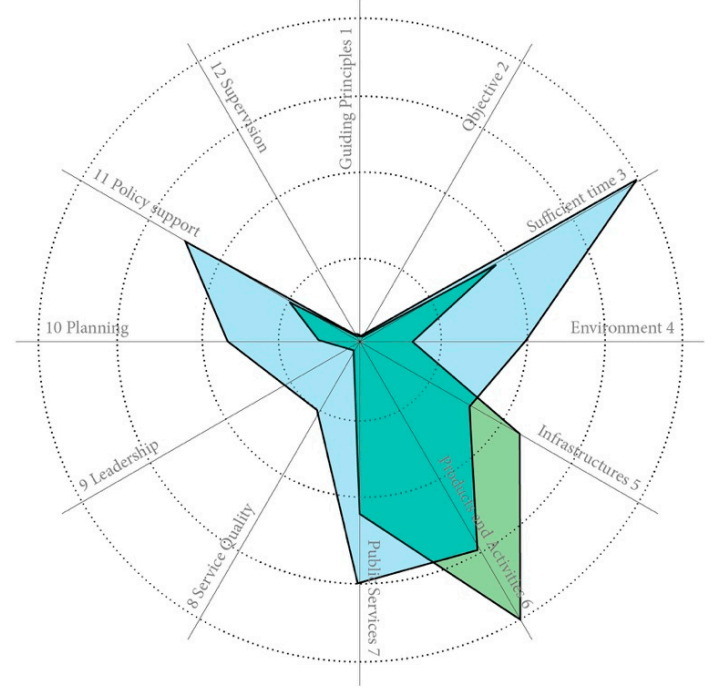

Figure 3. The 12 policies expressed by the ONTL with the respective correspondences with sustainable practice (SDGs) in blue and with design practice in green.

\subsection{Conclusion of Step 2: Public Policies in Practice}

From the comparison between governmental policies, expressed by the DS, and the practice experience, expressed by the 30 selected projects, two aspects are immediately visible (Figure 2; Figure 4): (1) some DSs occur several times while others are very little present; (2) the DS that have a greater number of occurrences are those that refer to Outline number 3, Sufficient time for national tourism and leisure $(3.9-61 \% ; 3.11-70 \% ; 3.12-56 \%)$, and to Outline number 6 , Product development and activity organization of national tourism and leisure $(6.3-74 \% ; 6.4 .1-100 \% ; 6.4 .2-30 \% ; 6.9-5 \%$; $6.10 .1-20 \% ; 6.10 .2-37 \% ; 6.12-5 \% ; 6.15-46 \%$ ), which already emerged in the Conclusion of Step 1 : Chinese Policies and sustainability. Specifically, those policies expressed by Outline number 3 are those that have the highest level of affinity with the SDGs (blue area in Figure 3), while the policies expressed by Outline number 6 are those that have the highest level of affinity with the design aspects (green area in Figure 3).

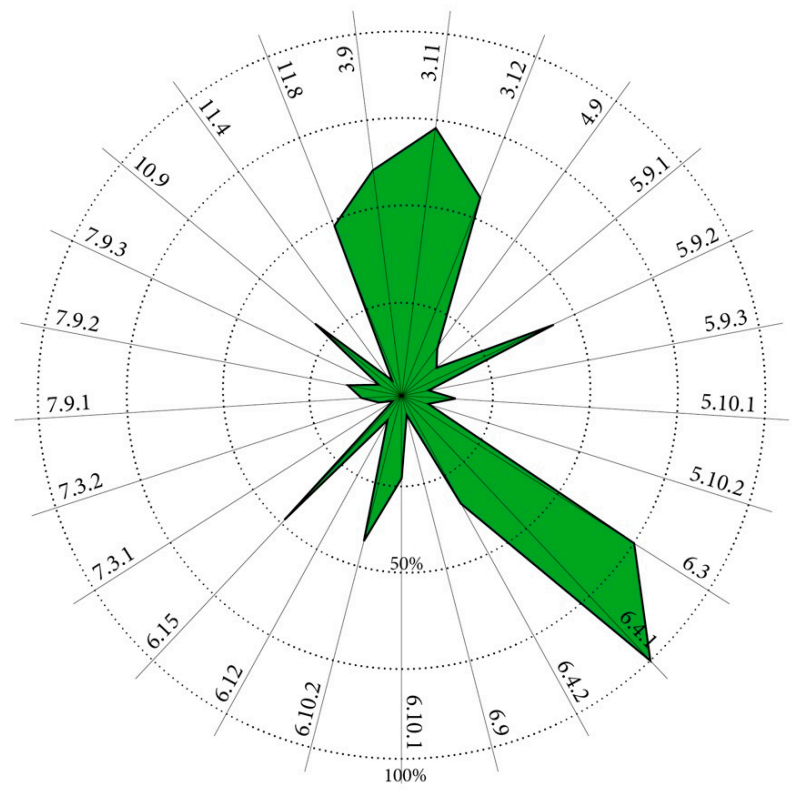

Figure 4. The 25 Design Strategies (DS) extrapolated by the research from the ONTL and their presence in the practices, as emerged from the study of the 30 cases; $100 \%$ is equal to 84 times. 
The presence of high values for Outline number 6 in this new correlation (policies-practice) can be considered as a confirmation of the previous correlation (policies-design) that linked Outline number 6 to design practice. On the contrary, the correlation between Outline number 3 and design practice represents a new relevant outcome which was not obvious at all: the design practice for the realization of projects for the sector of tourism and hospitality in China is demonstrating significant attention toward sustainability, based on internationally recognized parameters and guidelines.

With the support of Figure 4, some interesting aspects can be observed. Among the others, four aspects are relevant to discuss:

- heritage as a promoter of touristic activities and the role of culture as an entity increasingly valued by regenerative interventions must be highlighted. (DS 6.3.11, DS 6.4.1)

- wellbeing, as well as environmental and social sustainability, are areas in which the Public Policies are impacting the architectural production and the contemporary tourism supply. (DS 6.3)

- rural tourism as job creator for the countryside and factor to reduce inequalities. (DS 6.10.2, 6.10.9, 6.15)

- the number of projects based on non-governmental impulses is limited but extremely relevant for a country like China. (DS 11.8)

\subsection{Global Considerations: Sustainable Policies and Practice}

While tourism's impact on societies and territories is impressively high and often dangerous, good policies and practices can transform it into a force promoting welfare and protection, reaching that idea of "sustainability for development" that the United Nations are seeking. As we have seen, in China, this direction towards sustainable tourism and development has been going on for years, taking different forms according to the needs of the context, allowing important (mainly public) investments and producing important results for the economic, ecological and social fields. Touristic projects contribute to rediscovering the relation with nature and in increasing the local identity; but they also contribute to distributing more uniformly services, culture and job opportunities within an ample country afflicted by important inequalities such as China.

\subsubsection{Concept of Sustainability}

Having analyzed the concept of sustainability by the SDGs two results can be highlighted, one more thematic and one more methodological. The first is that Chinese policies face the concept of sustainability in a fairly broad way, touching specially the SDGs that are linked to the themes of infrastructure, education and consumption. The second reiterates the complexity of understanding the concept of sustainability in the tourism sector, as expressed by the current literature, showing how an analysis by the broad vision of the SDGs can allow an integral reading of the sustainability of public policies.

\subsubsection{Chinese Policies for Tourism, Sustainability and Design}

All the matches resulting from the comparisons between the Chinese policies for tourism and the international guidelines for sustainable development demonstrate that the Chinese government is conscious about the important role that tourism can play in reaching the goals for sustainable development in the next future. This aspect must definitely be seen as a positive attitude by the Chinese government trying to solve the contemporary inequalities and environmental alarms of this country. In particular, analyzing these "sustainable policies" emerges consciousness for the role of design, since the majority of the outlines present several policies related with design issues.

On the one side, this fact gives to the world of design (architecture, urban planning, industrial design, etc.) great responsibility in contributing to achieving the results expected by public policies.

On the other hand, it shows how the management of the built environment represents a challenge for the sustainable development of territories (whether urban or rural) and the Chinese government 
demonstrates awareness that the tourism sector cannot escape this challenge. Moreover, the search for policies in recent realizations has shown how, in fact, these policies are received and implemented in the Chinese practice, demonstrating attention toward this topic also by the practice. On the whole, a similar example of policies and practices can certainly be considered an important international reference, and, for the dimension of the in-bound tourism, the Chinese case opens scenarios of hope for the global phenomenon of tourism and leisure. For these reasons, the research opens up the possibility of considering China, an innovative country in sustainable tourism policies, with a rich portfolio of realized cases that for the Chinese richness of geographical and social differences, can be considered relevant for several other geographical areas and social realities.

\subsubsection{Directions of Sustainable Policies and Practice}

The results of the second phase highlight some aspects that can propose discussions about the directions in which the practice of tourism in China is currently moving in order to understand which sustainable policies are best implemented in practice by construction and management, and which others need greater attention in order to be actually considered effective. Among those which experience the greatest success in practice, the following can be highlighted:

- Tradition and Historical Heritage: "Historical places will be closer and accessible to citizens and communities" (DS 3.11) and "Tourism activities will promote fine traditional culture" (DS 6.4.1). This aspect introduces a very interesting issue regarding the role that historical heritage has within the architectural practice and the tourism activities. On the one hand, this means that the Chinese practice is moving toward a direction that gives value to historical heritages, protecting them and enhancing their cultural and economic values. On the other hand, it means that recent tourism activities are already benefiting from the richness of the Chinese culture, pushing interventions on its heritage. This is particularly relevant if we consider the contemporary Chinese cultural context, where the practice of recovery architectural heritage is a relatively recent tendency, with results that are slowly showing a maturing sensibility to this practice. The demand of tourism to work in environments whose historical and cultural value is clearly expressed can mean a positive impulse towards better design results, able to demonstrate a matured awareness and skill towards the theme of recovery.

- Rural-Urban: “The tourism services will be provided in the rural and urban context (DS 6.10.2), "The rural spaces for vacation will be promoted" (DS 6.15) and "The urban and rural planning will have consideration to lands for tourism and leisure, while improving their layout" (DS 10.9). Attention to the social problems in rural contexts combined with the awareness of the naturalistic potentialities for new types of "agro" tourism are already impacting these areas. Tourism and practice seem to succeed in one of the main goals of the Chinese contemporary policies, the Chinese 13th Five-year Plan (2016-2020) [24], which aims to reduce inequalities within the country.

- Life quality and Health: "Tourism and leisure products that improve life quality and physical health will be developed" (DS 6.3). The tendency to offer wellbeing-oriented tourist solutions is also being pursued in China, confirming the fact that the esteems by the Global Wellness Institute (GWI) indicate, for 2017, the wellness tourism market's size of $\$ 639$ billion in 2017, "growing more than twice as fast as general tourism". This is particularly relevant in the Asia-Pacific region, where the expenditure was $\$ 136.7$ billion and where the projected average annual growth rate for the period 2017-2022 is 13\% (which represents the highest percentage in the world) [62]. This means that policies and practices are already in line with the global tendencies and they are moving in the direction of a sectorial tourism which will create higher demand in the near future. Several margins to increase the economic and social impacts of the wellness tourism definitely exist (in particular related to services and products for health and physical care) but the Chinese reality shows capacity to deal with the topics.

- Private Sector: The Government will support, with specific policies, the micro, small and medium-sized enterprises related to the tourism sector (DS 11.8). This aspect is very significant 
within the Chinese context, where the private interventions are traditionally limited and marginalized in specific fields. The openness of the policies and the receptiveness of the practice is representing new conditions for Chinese tourism entrepreneurship, incentivized by new policies. While private entrepreneurship seems to already have adopted indications mainly for hospitality facilities (hotels, motels, restaurants, bar, etc.), cultural facilities such as museums, academies of art and sports centers, even if encouraged by policies, still have limited applications by the private sector.

Some considerations can also be made regarding the aspects that highlight some lacks, which can be grouped in the field of "services for support". In particular, from the research findings, it emerges that the policies that have the least realization are those that concern: (1) implementing information services for the disabled population (DS 5.10.2); (2) intensifying research and development of tourism infrastructure and equipment (DS 6.9); (3) reinforcing information regarding safety risks on tourism and leisure destinations (DS 7.3.1); (4) improving tourism transport services in railway, highway, waterway transport and civil aviation (DS 7.9.3); (5) encouraging non-governmental leisure facilities aimed at museums, academies of art and sports centers (DS 11.4). These lacks in the practice of policies implementation open opportunities to consider these fields as new frontiers (a) for entrepreneurs, who can see investments opportunities in these areas, and (b) for policy makers who can find some gaps in the incentives for the implementation of the related policies. Both cases can be the object of further research development.

\subsection{Limitations and Future Research Directions}

The fact that the research is mainly based on document analysis (policies and case studies) implies that the main limitations come from the documents and in particular, from their accessibility.

- Sources and impossibility to do field surveys: the analysis of case studies is based on already published documents, with the sole intention of highlighting the presence or absence of the indications of public policies. In fact, the cases were chosen from already validated sources (journals, architectural magazines, books, exhibitions, etc.) that published the 30 selected projects on the bases of their relevance in the economic, social and environmental issues. On the one hand, the fact that the research did not focus its attention on legitimizing the relevance of the projects, but just on providing a selection of already validated cases, homogenously distributed all around the People Republic and representing different categories of projects for tourism and leisure should be reconfirmed. In any case, what could be improved is the understanding of architectural and tourist projects. The opportunity to work in the field would allow to improve the reliability of the data.

- Language: Chinese, which is the language of the majority of the documents, represented a limitation, solved by the presence of a mother-language author. Nevertheless, the fact that the extended versions of the policies are written only in Chinese represents a partial limitation for a free understanding by the other authors.

- Projects on a large scale are not well represented: the indicator concerning DS on an infrastructure may have been evaluated as less important than the actual reality. In fact, there is a relative scarcity of projects that refer to infrastructures and large-scale projects. This quantitative limit is dictated by the choice to consider a typological distribution of projects based on reality, where precisely, large-scale infrastructure projects, even if they have a high impact, still represent a minority. Future research could assess the need to put a weight on "special" indicators as this DS.

Despite these three limitations, the researcher highlighted several relevant aspects and opened the path to the development of further work. In fact, this work is intended to be the basis for a more focused research program that could lead to following implementations.

- Focus: now that the relevant area of interest is clear, a focus on more specifically defined categories (geographical context, social environment or particular function) could be interesting. In this 
case, defining other parameters for the choice of the projects could be needed, also renewing and expanding the number of cases or outlining some specific indicators to analyze more deeply the single cases, even within field research.

- Observatory: observe the evolution of the practice, keeping the same indicators (DS) of this research and applying them to new case studies (after 2019). This allows to confront the results with those expressed by the present research and to observe how the practice will evolve in the next few years.

- Toolkit: designing a tool kit for policy makers, managers, designers and citizens. According to the directions of sustainable policies and practice in China, as emerged in this research (refer to 5.3.3. Directions of Sustainable Policies and Practice), it would be relevant to develop a tool kit for specific actions, addressed to policy makers, managers, designers and citizens to better understand their role in the touristic sector, to make decisions and to be better involved in the practice.

Author Contributions: Conceptualization, E.G., T.C. and M.N.; Investigation, E.G. and T.C.; Methodology, E.G. and T.C.; formal analysis, E.G.; Supervision, E.G.; Visualization, E.G., M.N. and R.E.A.; resources, T.C., E.G. and M.N.; data curation, E.G.; Writing-original draft preparation, E.G.; Writing-review and editing, T.C., E.G. and M.N.; funding acquisition, T.C., E.G. All authors have read and agreed to the published version of the manuscript.

Funding: This research was co-funded by the "Initiative On Campus Jobs" (Tecnologico de Monterrey, campus Leon, 2018), "Fondo para el financiamiento para la publicación de Artículos Científicos" (Tecnologico de Monterrey, 2019), and the "Shanghai 1000 Talent Plan" award number SX06077.

Acknowledgments: This research received financial support from two institutional bodies: the Tecnologico de Monterrey, with the "Initiative On Campus Jobs" and "Fondo para el financiamiento para la publicación de Artículos Científicos" under the scientific coordination of Emanuele Giorgi, and the Shanghai "1000 Talent Plan" award number SX06077, under the scientific coordination of Tiziano Cattaneo. The research project was performed within a long-term an international collaboration between Tecnologicio de Monterrey, campus Chihuahua, the Environmental Futures Lab. at the College of Design and Innovation, Tongji University in Shanghai and the China Lab. for Architecture and Urban Studies of the University of Pavia (Italy). Data and documents only available in Chinese language have been translated by Minqing Ni. The authors would like to thank all those who have provided valuable sources and comments on earlier versions of this paper, particularly Lou Yongqi, Aldo Cibic, Li Xiangning, Pablo Hernández Quiñones and Diego Grañena Puyo.

Conflicts of Interest: The authors declare no conflict of interest.

\section{Appendix A}

Table A1. Considerations regarding the Outlines for National Tourism and Leisure (ONTL).

\begin{tabular}{ll}
\hline ONTL Name & \multicolumn{1}{c}{ Comments } \\
\hline PART I. Guiding Principles and Objectives & The main principles of these outline and the reasons why it was considered necessary \\
are explained here: people are experimenting new needs, in particular for tourism and \\
leisure, and the supplies to these needs must be adequate to the general vision to build \\
a "prosperous society in China". With the description of these Guiding Principles, the \\
Chinese Government shows to be aware about the role that touristic activities can play \\
in improving the people's life quality, promote environment-friendly activities and \\
encouraging sustainable ways of production and consumption. In regards to the lack \\
Principles \\
of contents in terms of planning strategies this point has been eliminated from the \\
points to analyse in the "Punctual correlation" analyses.
\end{tabular}


Table A1. Cont.

\begin{tabular}{ll}
\hline ONTL Name & \multicolumn{1}{c}{ Comments } \\
\hline PART II. Major Tasks and Measures \\
\hline \\
This point refers to the role that, even if in two different ways, the public and private \\
bodies have in helping their employees having flexible and paid leave. This guideline \\
refers also to the educational entities, which holidays can be modified. As it is easily \\
understandable, this point has strong implication on the touristic and hospitality \\
sectors, on the infrastructures and on the activities required to supply this new \\
demand generated by these new policies. From the analyses of this point "Sufficient \\
time for national tourism and leisure" the planning strategies (PS) obtained are:
\end{tabular}

The possibility to easily access to touristic attractions is a goal at a short-medium term. Considering tourism, a form of knowledge and human right, the Chinese government wants to work along two lines: (1) making the visit cost to relevant touristic attractions lower, or even free, and (2) facilitate the accessibility to these attractions, through local tourism transportation and favourable treatment. From the analyses of this point

Better environment for

4 national tourism and leisure
"Better environment for national tourism and leisure" the planning strategies (PS) obtained are:

- $\quad$ Education tours will be introduced for schools and their students.

- $\quad$ Employees will be provided with tourism and leisure by the enterprises.

- Infrastructure for tourism transport should be incorporated to the public transport system.

- $\quad$ Free public entrance to museums and sites for patriotic education will be offered.

- $\quad$ The ticket prices for recreation sites will be reduced and will benefit different population groups
Improved infrastructure

5 for national tourism and leisure
This point relates with the infrastructures needed to create a strong supply system, able to receive the demand generate through the previous guidelines. Two points are interesting to note: (1) the different scale involved in the process of transformation (family inns, budget hotel, motels, city parks, streets, ports for cruise liners and yachts, metropolitan belts, villages and touristic towns) and (2) the sustainable approach to the interventions, related to the environmental resources and the social accessibility and integration. From the analyses of this point "Improved infrastructure for national tourism and leisure" the planning strategies (PS) obtained are:

- $\quad$ Leisure space will increase by building city parks, recreation belts around metropolis and for residents in villages and towns.

- $\quad$ Infrastructure such as family inns, hotels and motels will be promoted.

- $\quad$ Ports for aquatic mobility will be supported.

- To ensure accessibility to public spaces.

- Implement information services for the disabled population.

- $\quad$ Parks, afforested lands and public leisure spaces will be protected. 
Table A1. Cont.

\begin{tabular}{|c|c|}
\hline Name & Comments \\
\hline $\begin{array}{l}\text { Product } \\
\text { development } \\
\text { and activity } \\
\text { organization of } \\
\text { national } \\
\text { tourism and } \\
\text { leisure }\end{array}$ & $\begin{array}{l}\text { This sixth point underlines, as there are several reasons that can move the Tourism and } \\
\text { Leisure economy: from the healthcare to the sport and to the culture, several can be the } \\
\text { scopes to tourist. The Chinese Government wants to underline its attention to } \\
\text { encourage several different kinds of vacations. Anyway, it is not enough paying } \\
\text { attention to the purposes, but also to the tourists. For this reason, attention will be paid } \\
\text { for the different groups of people (seniors, women, children, people with disabilities, } \\
\text { etc.). Another point to be underlined is the intensification of the R\&D of tourism } \\
\text { infrastructures and equipment. From the analyses of this point "Product development } \\
\text { and activity organization of national tourism and leisure" the planning strategies (PS) } \\
\text { obtained are: } \\
\text { - } \quad \text { Tourism and leisure products that improve life quality and physical health will } \\
\text { be developed. } \\
\text { - Tourism activities will promote fine traditional culture. } \\
\text { - Cultural recreation and popular science education will be included in the } \\
\text { tourism field. } \\
\text { Research and development of tourism infrastructure and equipment will } \\
\text { be intensified. } \\
\text { Tourism will be offered for different groups of people, including the people } \\
\text { with disabilities. } \\
\text { The tourism services will be provided in the rural and urban context. } \\
\text { - Services and products that look after health and physical care and that include } \\
\text { cultural performance will be offered. } \\
\text { The rural spaces for vacation will be promoted. }\end{array}$ \\
\hline
\end{tabular}

Chinese Government takes care also about the services that must be present around a strong tourism and leisure national system. This point refers to the implementation of several topics: from the strengthening of the communication on destination and services, to the improvement of a better tourism transportation system, to the development of an educational system on tourism and leisure. From the analyses of this point "Well-developed public services for national tourism and leisure" the planning strategies (PS) obtained are:

Well-developed public services

7 for national tourism and leisure
- Safety risk information on tourism and leisure destinations will be reinforced.

- Improve the rescue system for tourists and other emergencies.

- $\quad$ To improve the direct relation between education models and vocational education with the tourism and leisure industry.

- $\quad$ Hygiene in tourism will be enhanced.

- $\quad$ To train tourism professionals to offer qualified services.

- Tourism information centers in public spaces and expressway service areas will be built.

- $\quad$ The road sign system will be improved.

- The tourism transport services in railway, highway, waterway transport and civil aviation will be improved.

- $\quad$ Ensure barrier-free services for population with disabilities.
Enhanced service quality

8 in national tourism and leisure
With this point, the will to promote self-discipline in the industry is exposed. The government requires a quality guarantee system of national tourism and leisure to enhance the value of the supply and to protect the interests of the customers. From the analyses of this point "Enhanced service quality in national tourism and leisure" the planning strategies (PS) obtained are:

- The application and accomplishment of quality standards of national tourism and leisure will be supervised.

Promote honest operation and discipline in the tourism industry.

- Across sectors and regions, the communications and coordination will be strengthened to protect the interest of consumers against fraud.

- To protect the legitimate rights and interests of operators and customers in the tourism and leisure market. 
Table A1. Cont.

\begin{tabular}{|c|c|c|}
\hline \multicolumn{2}{|c|}{ ONTL Name } & Comments \\
\hline \multicolumn{3}{|c|}{ PART III. Organization and Implementation } \\
\hline 9 & $\begin{array}{l}\text { Strong } \\
\text { leadership and } \\
\text { organization }\end{array}$ & $\begin{array}{l}\text { In this first point of the third part, for the organization and implementation of the } \\
\text { outline, the role of commissions, departments, associations and organizations is } \\
\text { delineated. Tourism and Leisure must be included in their official scopes and the } \\
\text { implementation of this industry should pass through their ordinary activities. In } \\
\text { regard to the lack of contents in terms of planning strategies this point has been } \\
\text { eliminated from the points to analyse in the "Punctual correlation" analyses. }\end{array}$ \\
\hline \multirow{4}{*}{10} & \multirow{4}{*}{$\begin{array}{l}\text { Sound planning } \\
\text { and guidance }\end{array}$} & $\begin{array}{l}\text { In this second point of the third part, for the organization and implementation of the } \\
\text { outline, the role of planning is delineated. Tourism and Leisure must be part of the } \\
\text { economic and social development plans at all levels. In particular, some land for } \\
\text { tourism and leisure must be considered in the urban and rural planning. From the } \\
\text { analyses of this point "Sound planning and guidance" the planning strategies (PS) } \\
\text { obtained are: }\end{array}$ \\
\hline & & $\begin{array}{l}\text { - The urban and rural planning will have consideration to lands for tourism and } \\
\text { leisure, while improving their layout. }\end{array}$ \\
\hline & & $\begin{array}{l}\text { - It will be given more guidance to different regions to develop their tourism and } \\
\text { leisure sectors and plans. }\end{array}$ \\
\hline & & $\begin{array}{l}\text { Social and economic development plans will incorporate national tourism } \\
\text { and leisure. }\end{array}$ \\
\hline \multirow{6}{*}{11} & \multirow{6}{*}{$\begin{array}{l}\text { Vigorous policy } \\
\text { support }\end{array}$} & $\begin{array}{l}\text { The Chinese Government will support all these goals presented in the ONTL, } \\
\text { increasing financial input into the public infrastructures for tourism and leisure and, at } \\
\text { the same time, supporting non-governmental and private bodies (with different } \\
\text { dimensions) in promoting tourism and leisure facilities. From the analyses of this } \\
\text { point "Vigorous policy support" the planning strategies (PS) obtained are: }\end{array}$ \\
\hline & & $\begin{array}{l}\text { - Non-governmental leisure facilities destined to museums, academies of art and } \\
\text { sports centers will be encouraged. }\end{array}$ \\
\hline & & - $\quad$ Governmental policy will support micro, small and medium-sized enterprises. \\
\hline & & $\begin{array}{l}\text { The financial governmental input into public service infrastructure for tourism } \\
\text { and leisure will gradually increase. }\end{array}$ \\
\hline & & High-quality tourism and leisure products will be developed with investment. \\
\hline & & $\begin{array}{l}\text { - Non-governmental sectors will be encouraged to invest in tourism and } \\
\text { leisure facilities. }\end{array}$ \\
\hline 12 & $\begin{array}{l}\text { Strong } \\
\text { supervision and } \\
\text { regulation }\end{array}$ & $\begin{array}{l}\text { The actuation of these policies and the supervision of the efforts done in this direction } \\
\text { are in charged to the local government. In regards to the lack of contents in terms of } \\
\text { planning strategies this point has been eliminated from the points to analyse in the } \\
\text { "Punctual correlation" analyses. }\end{array}$ \\
\hline
\end{tabular}

\section{Appendix B}

Table A2. List of the 30 case studies analysed.

\begin{tabular}{cllll}
\hline & Project Name/Year & \multicolumn{1}{c}{ Category/Function } & \multicolumn{1}{c}{ Location } & Designer \\
\hline 1 & $\begin{array}{l}\text { A. Mono Coffee } \\
\text { Shop, 2018 }\end{array}$ & $\begin{array}{l}\text { Service to the local } \\
\text { population-Shop }\end{array}$ & $\begin{array}{l}\text { Hangzhou, } \\
\text { Zhejiang }\end{array}$ & PROJECT Office \\
\hline 2 & $\begin{array}{l}\text { Anji Erlu Resort, } \\
2018\end{array}$ & $\begin{array}{l}\text { Development of business and } \\
\text { local entrepreneurship-Hotel }\end{array}$ & $\begin{array}{l}\text { The Design Institute of } \\
\text { Landscape and } \\
\text { Architecture, China } \\
\text { Academy of Art }\end{array}$ \\
\hline 3 & $\begin{array}{l}\text { Bamboo Craft } \\
\text { Village, 2018 }\end{array}$ & $\begin{array}{l}\text { Development of cultural } \\
\text { activities-Cultural Center }\end{array}$ & $\begin{array}{l}\text { Daomingzhen, } \\
\text { Sichuan }\end{array}$ & Archi-Union Architects \\
\hline
\end{tabular}


Table A2. Cont.

\begin{tabular}{|c|c|c|c|c|}
\hline & Project Name/Year & Category/Function & Location & Designer \\
\hline 4 & $\begin{array}{l}\text { Chatouya Visitor } \\
\text { Center, } 2017\end{array}$ & $\begin{array}{l}\text { Development of tourism } \\
\text { facilities and services-Visitor } \\
\text { Center }\end{array}$ & $\begin{array}{l}\text { Tianyu, Xi'an, } \\
\text { Shanxi }\end{array}$ & Tumushi Architects \\
\hline 5 & $\begin{array}{l}\text { Courtyard-Wayuan, } \\
2018\end{array}$ & $\begin{array}{l}\text { Development of business and } \\
\text { local entrepreneurship-Hotel }\end{array}$ & Houhai, Beijing & $\begin{array}{l}\text { Basic Architecture } \\
\text { Studio }\end{array}$ \\
\hline 6 & $\begin{array}{l}\text { Dafa Canal Tourist } \\
\text { Information Center, } \\
2018\end{array}$ & $\begin{array}{l}\text { Development of tourism } \\
\text { facilities and } \\
\text { services-Information Center }\end{array}$ & Zunyi, Guizhou & Atelier ZJJZ \\
\hline 7 & $\begin{array}{l}\text { Hakka Indenture } \\
\text { Museum, } 2017\end{array}$ & $\begin{array}{l}\text { Development of cultural } \\
\text { activities-Museum }\end{array}$ & $\begin{array}{l}\text { Songyang County, } \\
\text { Lishui, Zhejian }\end{array}$ & DnA architects \\
\hline 8 & $\begin{array}{l}\text { Hangzhou Senbo } \\
\text { Resort 'Park-Star } \\
\text { Cube', } 2019\end{array}$ & $\begin{array}{l}\text { Development of business and } \\
\text { local entrepreneurship-Hotel }\end{array}$ & $\begin{array}{l}\text { Hangzhou, } \\
\text { Zhejiang }\end{array}$ & $\begin{array}{l}\text { The Design Inst. of } \\
\text { Landscape and } \\
\text { Architecture, China } \\
\text { Academy of Art }\end{array}$ \\
\hline 9 & $\begin{array}{l}\text { History Museum of } \\
\text { Qifeng Village, } \\
2018\end{array}$ & $\begin{array}{l}\text { Development of cultural } \\
\text { activities-Museum }\end{array}$ & $\begin{array}{l}\text { Qifeng Village, } \\
\text { Chizhou City, } \\
\text { Anhui }\end{array}$ & SUP Atelier \\
\hline 10 & $\begin{array}{l}\text { Hiuxin Retreats, } \\
2018\end{array}$ & $\begin{array}{l}\text { Development of business and } \\
\text { local entrepreneurship-Hotel }\end{array}$ & $\begin{array}{l}\text { Miaoxing Town, } \\
\text { Zhejiang }\end{array}$ & MAaP architects \\
\hline 11 & $\begin{array}{l}\text { Hotel of Septour, } \\
2017\end{array}$ & $\begin{array}{l}\text { Development of business and } \\
\text { local entrepreneurship-Hotel }\end{array}$ & $\begin{array}{l}\text { Deqing, Zhejiang, } \\
\text { China }\end{array}$ & Temp Architects \\
\hline 12 & $\begin{array}{l}\text { Island Conference } \\
\text { Hotel, } 2018\end{array}$ & $\begin{array}{l}\text { Development of business and } \\
\text { local entrepreneurship-Hotel }\end{array}$ & $\begin{array}{l}\text { Zhoushan, } \\
\text { Zhejiang }\end{array}$ & Gad architects \\
\hline 13 & $\begin{array}{l}\text { Jianamani Visitor } \\
\text { Center, } 2013\end{array}$ & $\begin{array}{l}\text { Development of tourism } \\
\text { services and cultural } \\
\text { activities_-Visitor Center }\end{array}$ & Yushu, Qinghai & TeamMinus architects \\
\hline 14 & $\begin{array}{l}\text { Kangka } \\
\text { Zhouzhuang } \\
\text { Tourist Resort } \\
\text { Aquatic Club, } 2014\end{array}$ & $\begin{array}{l}\text { Development of business and } \\
\text { local entrepreneurship-Hotel }\end{array}$ & Suzhou, Jiangsu & UDG China \\
\hline 15 & $\begin{array}{l}\text { Library on the } \\
\text { Quay, } 2014\end{array}$ & $\begin{array}{l}\text { Development of cultural } \\
\text { activities-Library }\end{array}$ & Tongling, Anhui & ATA Studio \\
\hline 16 & $\begin{array}{l}\text { Lost Villa Boutique } \\
\text { Hotel in Yucun, } \\
2017\end{array}$ & $\begin{array}{l}\text { Development of business and } \\
\text { local entrepreneurship-Hotel }\end{array}$ & $\begin{array}{l}\text { Moganshan Zhen, } \\
\text { Zhejiang }\end{array}$ & $\begin{array}{l}\text { NATURALBUILD } \\
\text { architects }\end{array}$ \\
\hline 17 & $\begin{array}{l}\text { M2 Tourist Port at } \\
\text { Bai Lianjing, } 2018\end{array}$ & $\begin{array}{l}\text { Development of infrastructure } \\
\text { for tourism-Tourist Terminal }\end{array}$ & Shanghai & $\begin{array}{l}\text { TJAD Original Design } \\
\text { Studio }\end{array}$ \\
\hline 18 & Mica-Bar, 2018 & $\begin{array}{l}\text { Development of business and } \\
\text { local } \\
\text { entrepreneurship-restaurant } \\
\text { and bar }\end{array}$ & $\begin{array}{l}\text { Wangjaituan Town, } \\
\text { Weihai, Shandong }\end{array}$ & $\begin{array}{l}\text { 3andwich Design/He } \\
\text { Wei Studio }\end{array}$ \\
\hline 19 & $\begin{array}{l}\text { Nanxianglou Art } \\
\text { Hotel, } 2018\end{array}$ & $\begin{array}{l}\text { Development of local } \\
\text { entrepreneurship-Hotel and } \\
\text { art gallery }\end{array}$ & $\begin{array}{l}\text { Gankeng Old } \\
\text { Town, Shenzhen, } \\
\text { Guangdong }\end{array}$ & PleasantHouse Design \\
\hline 20 & $\begin{array}{l}\text { Ruralation } \\
\text { Shenaoli Library, } \\
2015\end{array}$ & $\begin{array}{l}\text { Development of cultural } \\
\text { activities and local } \\
\text { business-Library }\end{array}$ & Shenaoli, Zhejiang & $\begin{array}{l}\text { Zhang Lei/AZL } \\
\text { Architects }\end{array}$ \\
\hline 21 & $\begin{array}{l}\text { Rustic Charm Inn, } \\
2018\end{array}$ & $\begin{array}{l}\text { Development of business and } \\
\text { local } \\
\text { entrepreneurship-Guesthouse } \\
\text { hotel }\end{array}$ & $\begin{array}{l}\text { Minyi village, } \\
\text { Shanghai }\end{array}$ & Ams architects \\
\hline
\end{tabular}


Table A2. Cont.

\begin{tabular}{|c|c|c|c|c|}
\hline & Project Name/Year & Category/Function & Location & Designer \\
\hline 22 & $\begin{array}{l}\text { Shaoxing Hotel, } \\
2018\end{array}$ & $\begin{array}{l}\text { Development of business for } \\
\text { tourism-Hotel }\end{array}$ & Shaoxing & UAD architects \\
\hline 23 & $\begin{array}{l}\text { Ranwu Lake } \\
\text { Campsite, } 2017\end{array}$ & $\begin{array}{l}\text { Development of local business } \\
\text { and cultural } \\
\text { activities-multifunctional } \\
\text { complex }\end{array}$ & Ranwu Town, Tibet & $\begin{array}{l}\text { Xiao Yin Architecture } \\
\text { Design Firm }\end{array}$ \\
\hline 24 & $\begin{array}{l}\text { Stray Birds Art } \\
\text { Hotel, } 2018\end{array}$ & $\begin{array}{l}\text { Development of business and } \\
\text { local entrepreneurship-Hotel } \\
\text { and art gallery }\end{array}$ & $\begin{array}{l}\text { Chenjiapu Village, } \\
\text { Lishui, Zhejiang }\end{array}$ & gad line + studio \\
\hline 25 & $\begin{array}{l}\text { Sury Resort No.3, } \\
2017\end{array}$ & $\begin{array}{l}\text { Development of business for } \\
\text { tourism-Guesthouse and } \\
\text { recreational facilities }\end{array}$ & $\begin{array}{l}\text { Mogan Moutain, } \\
\text { Zhejiang }\end{array}$ & Atelier XÜK \\
\hline 26 & $\begin{array}{l}\text { Tourist Center of } \\
\text { Anlong Limestone } \\
\text { Resort, } 2017\end{array}$ & $\begin{array}{l}\text { Service to the local population } \\
\text { and Development of business } \\
\text { and local } \\
\text { entrepreneurship_-various } \\
\text { functions }\end{array}$ & $\begin{array}{l}\text { Dushan Town, } \\
\text { Guizhou }\end{array}$ & $\begin{array}{l}\text { 3andwich Design/He } \\
\text { Wei Studio }\end{array}$ \\
\hline 27 & $\begin{array}{l}\text { Treasure House of } \\
\text { Shanghai Himalaya } \\
\text { Art Museum, } 2017\end{array}$ & $\begin{array}{l}\text { Development of cultural } \\
\text { activities-reconstruction of } \\
\text { an ancient timber house }\end{array}$ & Shanghai & $\begin{array}{l}\text { Shan Xiang } \\
\text { Architectural Design } \\
\text { Co., Ltd. }\end{array}$ \\
\hline 28 & $\begin{array}{l}\text { Vita-The Fortune } \\
\text { Bridge, } 2017\end{array}$ & $\begin{array}{l}\text { Development of business and } \\
\text { cultural } \\
\text { activities_refurbishment of a } \\
\text { bridge-restaurant }\end{array}$ & Zhengzhou, Henan & ARIZON DESIGN \\
\hline 29 & $\begin{array}{l}\text { Xinzhai Coffee } \\
\text { Manor, } 2018\end{array}$ & $\begin{array}{l}\text { Development of local business } \\
\text { and cultural } \\
\text { activities-multifunctional } \\
\text { complex }\end{array}$ & $\begin{array}{l}\text { Bawan Village, } \\
\text { Yunnan }\end{array}$ & $\begin{array}{l}\text { TAO_-Trace } \\
\text { Architecture Office }\end{array}$ \\
\hline 30 & $\begin{array}{l}\text { Yiyuan Xiaozhu, } \\
2018\end{array}$ & $\begin{array}{l}\text { Development cultural } \\
\text { activities and Service to the } \\
\text { local population-restoration } \\
\text { of Chinese garden }\end{array}$ & Chengdu, Sichuan & Dachuan Architects \\
\hline
\end{tabular}

\section{References}

1. Cattaneo, T.; De Lotto, R. Rural-Urbanism Architecture. Design Strategies for Small Towns' Development; Alinea Editore: Firenze, Italy, 2015.

2. World Travel and Tourism Council. Travel and Tourism Economic Impact 2017. Available online: https: //www.wttc.org/publications/ (accessed on 14 January 2018).

3. He, W.; Wang, Y.; Liu, H.; Qian, J.; Zhuang, Q. What Influence Chinese Rural Migrant Workers' Opportunity Identification Level in Tourism Industry. In Advances in Economics, Business and Management Research; Proceedings of the 1st International Conference on Business, Economics, Management Science (BEMS 2019), Hangzhou, China, 20-21 April 2019; Zhou, H.Q., Kang, Q., Chen, Y.Y., Eds.; Atlantis Press: Beijing, China, 2019; Volume 80, pp. 42-50.

4. Liu, Y.; Li, Y.; Li, L. A panel data-based analysis of factors influencing market demand for Chinese outbound tourism. Asia Pac. J. Tour. Res. 2018, 23, 667-676. [CrossRef]

5. Su, M.M.; Wall, G.; Xu, K. Heritage tourism and livelihood sustainability of a resettled rural community: Mount Sanqingshan World Heritage Site, China. J. Sustain. Tour. 2016, 24, 735-757. [CrossRef]

6. Cattaneo, T.; Giorgi, E.; Barquero, V.; Mendez, A. Mexican Nature based Solutions for the improvement of rural communities, within tourism development. Urban. Inf. 2018, 272, 782-785.

7. Hall, C.M.; Gossling, S.; Scott, D. (Eds.) The Routledge Handbook of Tourism and Sustainability; Routledge: London, UK, 2015. 
8. Qiu, H.; Fan, D.X.; Lyu, J.; Lin, P.M.; Jenkins, C.L. Analyzing the Economic Sustainability of Tourism Development: Evidence from Hong Kong. J. Hosp. Tour. Res. 2019, 43, 226-248. [CrossRef]

9. Legrand, W.; Chen, J.S.; Sloan, P. Sustainability in the Hospitality Industry 2nd Ed: Principles of Sustainable Operations; Routledge: London, UK, 2013.

10. Jones, P.; Hillier, D.; Comfort, D. Sustainability in the hospitality industry: Some personal reflections on corporate challenges and research agendas. Int. J. Contemp. Hosp. Manag. 2016, 28, 36-67. [CrossRef]

11. Li, P.; Ryan, C.; Cavec, J. Chinese rural tourism development: Transition in the case of Qiyunshan, Anhui. -2008-2015. Tour. Manag. 2016, 55, 240-260. [CrossRef]

12. Shixiu, W.; Hua, P. Tourism development, rights consciousness and the empowerment of Chinese historical village communities. Tour. Geogr. 2014, 16, 772-784.

13. Tang, X. The historical evolution of China's tourism development policies (1949-2013) —A quantitative research approach. Tour. Manag. 2017, 58, 259-269. [CrossRef]

14. Chen, X.; Huang, F. Temporal Change of Regional Disparity in Chinese Inbound Tourism. Acta Geogr. Sin. 2006, 61, 1271-1280.

15. Hsu, C.H.C.; Huang, S.S. Reconfiguring Chinese cultural values and their tourism implications. Tour. Manag. 2016, 55, 230-242. [CrossRef]

16. World Tourism Organization; UNDP; PWC. Tourism and the Sustainable Development Goals—Journey to 2030; UNWTO: Madrid, Spain, 2017.

17. Nyíri, P. Scenic Spots: Chinese Tourism, the State, and Cultural Authority; University of Washington Press: Washington, DC, USA, 2006.

18. Zhuang, X.; Hong, Z.; Suqiu, D. Institutional ethical analysis of resident perceptions of tourism in two Chinese villages. Tour. Geogr. 2014, 16, 785-798.

19. Cattaneo, T.; Giorgi, E.; Ni, M. Landscape, Architecture and Environmental Regeneration: A Research by Design Approach for Inclusive Tourism in a Rural Village in China. Sustainability 2019, 11, 128. [CrossRef]

20. Honggang, X.; Xiaojuan, W.; Xiaojun, F. Rethinking authenticity in the implementation of China's heritage conservation: The case of Hongcun Village. Tour. Geogr. 2014, 16, 799-811.

21. Korstanje, M.E.; George, B.P. Seven Religious Tourism in the Ideological Framework of Chinese Tourism Education. In Religious Tourism in Asia: Tradition and Change through Case Studies and Narratives; Yasuda, S., Raj, R., Griffin, K., Eds.; Cabi: Boston, MA, USA, 2018; pp. 58-66.

22. Likun, C. Cultural impact of modernization and tourism on Dai villages in Xishuangbanna, China. Tour. Geogr. 2014, 16, 757-771.

23. De Lotto, R.; Cattaneo, T.; Giorgi, E.; Venco, E. Coherences and Differences among EU, US and PRC. Approaches for Rural Urban Development: Interscalar and Interdisciplinary Analysis. Sustainability 2017, 9 , 537. [CrossRef]

24. Central Committee of the Communist Party of China (CPC). The 13th Five-Year Plan for Economic and Social Development of the People's Republic of China (2016-2020); Central Compilation \& Translation Press: Beijing, China, 2015.

25. Guo, Y.; Jiang, J.; Li, S. A Sustainable Tourism Policy Research Review. Sustainability 2019, 11, 3187. [CrossRef]

26. Zeng, B.; Ryan, C. Assisting the poor in China through tourism development: A review of research. Tour. Manag. 2012, 33, 239-248. [CrossRef]

27. Li, M.; Wu, B.; Cai, L. Tourism development of World Heritage Sites in China: A geographic perspective. Tour. Manag. 2008, 29, 308-319. [CrossRef]

28. Wang, Y.; Bramwell, B. Heritage protection and tourism development priorities in Hangzhou, China: A political economy and governance perspective. Tour. Manag. 2012, 33, 988-998. [CrossRef]

29. United Nations. General Assembly UN (2015) Resolution Adopted by the General Assembly on 25 September 2015. Transforming our World: The 2030 Agenda for Sustainable Development. Available online: https:/www.un.org/en/development/desa/population/migration/generalassembly/docs/ globalcompact/A_RES_70_1_E.pdf (accessed on 26 June 2018).

30. Groat, L.N.; Wang, D. Architectural Research Methods, 2nd ed.; Wiley: Hoboken, NJ, USA, 2013.

31. Choy, D.J.L.; Dong, G.L.; Wen, Z. Tourism in PR China: Market trends and changing policies. Tour. Manag. 1986, 7, 197-201. [CrossRef]

32. Dai, B.; Jiang, Y.; Yang, L.; Ma, Y. China's outbound tourism-Stages, policies and choices. Tour. Manag. 2017, 58, 253-258. [CrossRef] 
33. Chen, G.; Bao, J. Path dependence in the evolution of resort governance models in China. Tour. Geogr. 2014, 16, 812-825. [CrossRef]

34. Zhang, G. China's Tourism Since 1978: Policies, Experiences and Lessons Learned. In Tourism in China; Kaye, S.C., Zhang, G., Alan, A.L., John, A., Lawrence, Y., Eds.; Routledge: New York, NY, USA, 2008.

35. Pan, L.J.; Zheng, H.S. Tourism Development, Environment and Policies: Differences between Domestic and International Tourists. Sustainability 2019, 11, 15.

36. Richter, L.K. Political implications of Chinese tourism policy. Ann. Tour. Res. 1983, 10, 395-413. [CrossRef]

37. Ryan, C.; Huimin, G.; Meng, F. Community Participation and Social Impacts of Tourism. In Tourism in China. Destination, Cultures and Communities; Ryan, C., Huimin, G., Eds.; Routledge: New York, NY, USA, 2008; pp. 239-258.

38. Xu, H.; Sofield, T. Sustainability in Chinese development tourism policies. Curr. Issues Tour. 2016, 19, 1337-1355. [CrossRef]

39. Verdini, G. The New Urbanisation Plan (2014-2020) and the Challenge for the Urban Governance Regime of Midland China. In Proceedings of the International Conference, Urban Futures-Squaring Circles: Europe, China and the World in 2050, Lisbon, Portugal, 10-11 October 2014; Bina, O., Balula, L., Ricci, A., Eds.; Institute of Social Science of the University of Lisbon and Calouste Gulbenkian Foundation: Lisbon, Portugal, 2014; p. 88.

40. International Labour Organization. Regulations on Paid Annual Leave for Employees. Available online: http://www.ilo.org/dyn/travail/docs/372/Regulations\%20on\%20Paid\%20Annual\%20Leave\%20for\% 20Employees\%20-\%20www.junhe.com.pdf (accessed on 19 May 2018).

41. World Tourism Organization. Secretariat Bureau of the General Office of the State Council, PRC (2013) Notice on the Publication of The Outline for National Tourism and Leisure (2013-2020) by the General Office of the State Council. UNWTO Files. Available online: http://cf.cdn.unwto.org/sites/all/files/pdf/the_outline_for_ national_tourism_and_leisure_2013-2020.pdf (accessed on 24 June 2018).

42. Jameskennell. Kennell, James (2013) China's New Tourism Policy 2013-2020. Available online: https: //jameskennell.com/2013/04/02/chinas-new-tourism-policy-2013-2020/ (accessed on 24 June 2018).

43. World Tourism Organization. China's New National Tourism Strategy Set to Increase Outbound Tourism. UNWTO Press Release. Available online: http://media.unwto.org/en/press-release/2013-03-25/china-s-newnational-tourism-strategy-set-increase-outbound-tourism (accessed on 26 June 2018).

44. World Tourism Organization. China's New Landmark Tourism Strategy: The Outline for National Tourism and Leisure (2013-2020). UNWTO Regional Department for Asia and the Pacific. Available online: http://asiapacific.unwto.org/en/news/2013-03-21/china-s-new-landmark-tourism-strategy-outlinenational-tourism-and-leisure-2013-2020 (accessed on 26 June 2018).

45. Bowden, J. Pro-poor tourism and the Chinese experience. Asia Pac. J. Tour. Res. 2005, 10, 379-398. [CrossRef]

46. Fan, C.; Wei, T. Effectiveness of integrated low-carbon technologies: Evidence from a pilot agricultural experiment in Shanghai. Int. J. Clim. Chang. Strateg. Manag. 2016, 8, 758-776. [CrossRef]

47. Li, X.; Mo, W.; Gros, R. Architecture China: Building a Future Countryside; The Images Publishing Group: Melbourne, Australia, 2018.

48. Ma, H.; Wang, K. Ruralation Shenaoli in Zhejiang. Inter. Des. Constr. 2016, 4, 118-121.

49. Wu, Z.; Guan, L. Urban implantation in rural China: Three representative works on rural construction in ancient villages, Zhejiang. In Proceedings of the 11th International Symposium on Architectural Interchanges in Asia (ISAIA 2016), Sendai, Japan, 20-23 Setember 2016.

50. De Lucchi, M. Povertà. Domus. 28 October 2018. Available online: https://www.domusweb.it/en/issues/2018/ 1028.html (accessed on 10 December 2019).

51. Zhang, L. Ruralation Shenaoli Library, Tonglu. CDC: London, UK. 2018. Available online: https://www. chinadesigncentre.com/works/ruralation-shenaoli-library-tonglu.html (accessed on 10 December 2019).

52. Hardy, J. Travels in China with the Sustainable Rural Construction Forum. Green by John. 2015. Available online: https://greenbyjohn.com/travels-in-china-with-the-sustainable-rural-construction-forum/ (accessed on 10 December 2019).

53. Su, X.; Song, C.; Sigley, G. The Uses of Reconstructing Heritage in China: Tourism, Heritage Authorization, and Spatial Transformation of the Shaolin Temple. Sustainability 2019, 11, 411. [CrossRef]

54. Dike, J. This Chinese Hotel Is Your Perfect Home Away From Home; HYPEBEAST, 2018. Available online: https://hypebeast.com/2018/2/lost-villa-boutique-hotel-china (accessed on 10 December 2019). 
55. Lost Villa Boutique Hotel in Yucun, Budcs. Available online: http://www.budcs.com/cluster/854439.html (accessed on 10 December 2019).

56. Wong, J. Lost Villa Boutique Hotel in Yucun/NATURALBUILD. ArchDaily. 2017. Available online: https:// www.archdaily.com/888066/lost-villa-boutique-hotel-in-yucun-naturalbuild (accessed on 10 December 2019).

57. Jianamani Visitor Center/TeamMinus. ArchDaily. 2015. Available online: https://www.archdaily.com/772575/ jianamani-visitor-center-teaminus/ (accessed on 10 December 2019).

58. Archmarathon: Speech TeamMinus_Project Jianamani Visitor Centre. YouTube. 2015. Available online: https://www.youtube.com/watch?v=B6HKYYLKYAM (accessed on 10 December 2019).

59. Amy Frearson, A. Jianamani Visitor Centre by Atelier TeamMinus. Dezeen. 2013. Available online: https: //www.dezeen.com/2013/10/29/jianamani-visitor-centre-by-atelier-teamminus/ (accessed on 10 December 2019).

60. Golden, E.M. Building from Tradition; Routledge: New York, NY, USA, 2018.

61. Wang, F.; Dong, X. Skeleton and Experience Architectural Renovation of the Mountainous Hotel of Septuor. Archit. J. 2017, 3, 50-59.

62. Global Wellness Tourism Economy; Global Wellness Institute, 2018; p. vii. Available online: https: //globalwellnessinstitute.org/wp-content/uploads/2018/11/GWI_GlobalWellnessTourismEconomyReport. pdf (accessed on 10 December 2019).

(C) 2020 by the authors. Licensee MDPI, Basel, Switzerland. This article is an open access article distributed under the terms and conditions of the Creative Commons Attribution (CC BY) license (http://creativecommons.org/licenses/by/4.0/). 